\title{
USGS/WRIR--96-4281
}

\section{THE ONE-DIMENSIONAL COMPRESSION METHOD FOR EXTRACTION OF PORE WATER FROM UNSATURATED TUFF AND EFFECTS ON PORE-WATER CHEMISTRY}

\section{U.S. GEOLOGICAL SURVEY}

Water-Resources Investigations Report 96-4281

\section{RECEIVED \\ MAY 261998 \\ OSTI}

\section{MASTER}

DISTRIBUTION OF THS DOCUREN IS UWHATE

* Prepared in cooperation with the NEVADA OPERATIONS OFFICE,

U.S. DEPARTMENT OF ENERGY, under Interagency Agreement DE-AI08-92NV10874

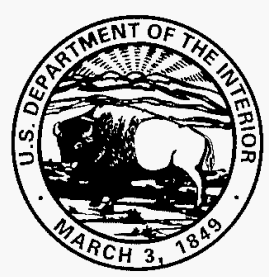




\section{The One-Dimensional Compression Method For Extraction of Pore Water From Unsaturated Tuff and Effects On Pore-Water Chemistry}

by Jerry D. Higgins, Paul A. Burger, Colorado School of Mines, Golden, Colorado; and In C. Yang, U.S. Geological Survey, Denver, Colorado

U.S. GEOLOGICAL SURVEY

Water-Resources Investigations Report 96-4281

Prepared in cooperation with the NEVADA OPERATIONS OFFICE,

U.S. DEPARTMENT OF ENERGY, under

Interagency Agreement DE-Al08-92NV10874

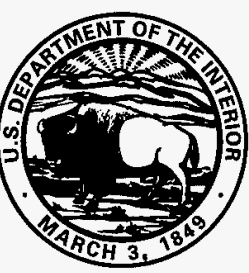




\title{
U.S. DEPARTMENT OF THE INTERIOR BRUCE BABBITT, Secretary
}

\author{
U.S. GEOLOGICAL SURVEY \\ Gordon P. Eaton, Director
}

The use of firm, trade, and brand names in this report is for identification purposes only and does not constitute endorsement by the U.S. Geological Survey.

For additional information write to:

Chief, Earth Science Investigations Program Yucca Mountain Project Branch

U.S. Geological Survey

Box 25046, Mail Stop 421

Denver Federal Center

Denver, CO 80225-0046
Copies of this report can be purchased from:

U.S. Geological Survey

Branch of Information Services

Box 25286

Denver, CO 80225-0286 


\section{DISCLAIMER}

This report was prepared as an account of work sponsored by an agency of the United States Government. Neither the United States Government aor any agency thereof, nor any of their employees, makes any warranty, express or implied, or assumes any legal liability or responsibility for the accuracy, completeness, or usefulness of any information, apparatus, product, or process disclosed, or represents that its use would not infringe privately owned rights. Reference herein to any specific commercial product, process, or service by trade name, trademark, manufacturer, or otherwise does not necessarily constitute or imply its endorsement, recommendation, or favoring by the United States Government or any agency thereof. The views and opinions of authors expressed herein do not necessarily state or reflect those of the United States Government or any agency thereof. 


\section{CONTENTS}

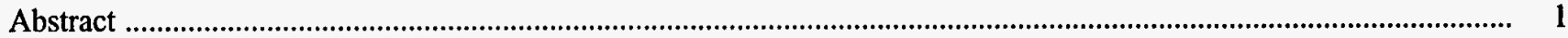

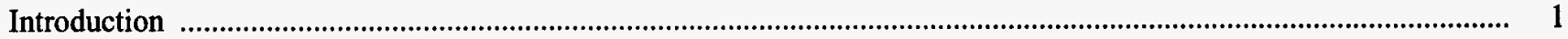

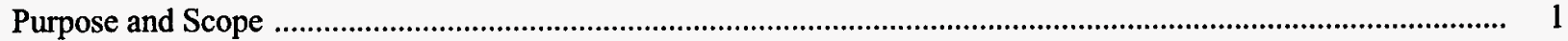

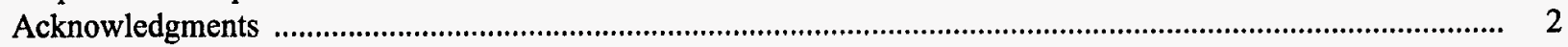

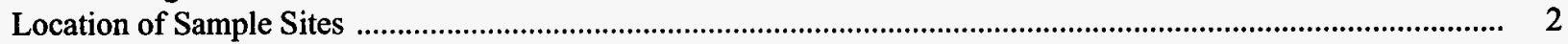

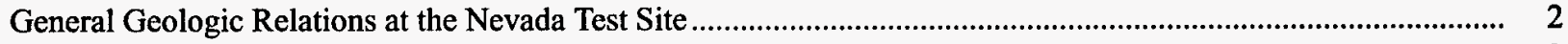

Review of Previous Work ............................................................................................................................................ $\quad 2$

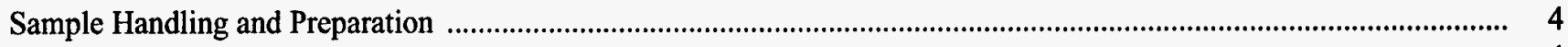

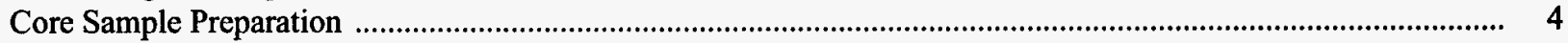

Water Sample Handling …………………………………………………………………………………….. 5

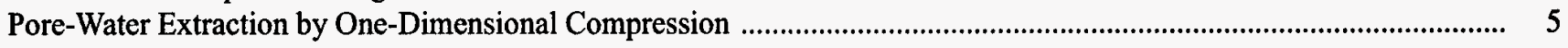

Design of One-Dimensional Pore-Water-Extraction Cell …………………………………………………….... $\quad 5$

Operation of One-Dimensional Pore-Water-Extraction Cell ................................................................................ $\quad 7$

Design of the High-Pressure One-Dimensional Compression Cell ....................................................................... 8

Operation of the High-Pressure One-Dimensional Compression Pore-Water Extraction Cell .................................... 10

Results of Compression Tests ............................................................................................................................ 10

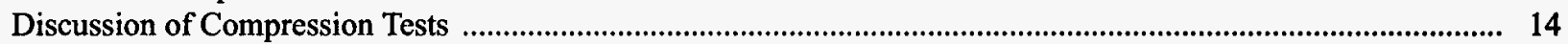

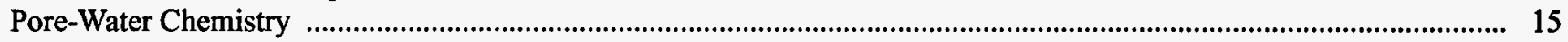

Chemical Analyses of Pore Water .................................................................................................................. 15

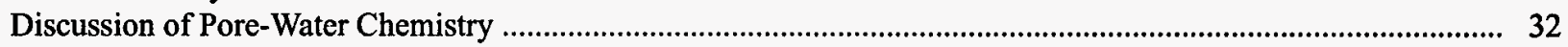

Potential Mechanisms for Changes in Pore-Water Chemistry .............................................................................. 32

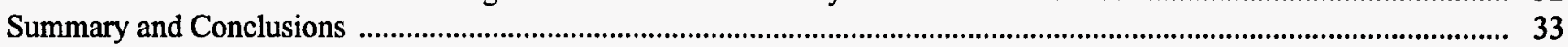

Selected References ……………………………………………………………………………………………. 33

FIGURES

1. Map showing location of sampling sites on and near the Nevada Test Site ……………………………...................... 2

2-4. Diagrams showing:

2. Generalized geologic relations at Yucca Mountain and Rainier Mesa ............................................................... 3

3. One-dimensional compression cell .............................................................................................................. $\quad 6$

4. Drainage plates used in one-dimensional compression cell............................................................................. $\quad 7$

5. Graph showing typical loading history for one-dimensional compression pore-water extraction test ........................ 8

6. Diagram showing high-pressure one-dimensional compression cell …………………………………....................... 9

7-19. Graphs showing:

7. Typical loading history for high-pressure one-dimensional compression pore-water extraction test...

8. Typical relation between axial stress and axial strain for one-dimensional compression of a nonwelded tuff core

9. Typical relation between axial stress and axial strain for one-dimensional compression of a densely welded tuff core

10. Relation between degree of saturation and degree of success for nonwelded tuff using one-dimensional and high-pressure one-dimensional compression.

11. Relation between degree of saturation and degree of success for partially welded tuff using one-dimensional and high-pressure one-dimensional compression.

12. Relation between degree of saturation and degree of success for densely welded tuff using one-dimensional and high-pressure one-dimensional compression.

13. Relation between moisture content and degree of success for nonwelded tuff using one-dimensional and high-pressure one-dimensional compression.

14. Relation between moisture content and degree of success for partially welded tuff using one-dimensional and high-pressure one-dimensional compression. 
15. Relation between moisture content and degree of success for densely welded tuff using one-dimensional and high-pressure one-dimensional compression

16. Relation between degree of saturation and volume of water extracted for nonwelded tuff using one-dimensional and high-pressure one-dimensional compression

17. Relation between degree of saturation and volume of water extracted for partially welded tuff using one-dimensional and high-pressure one-dimensional compression.

18. Relation between degree of saturation and volume of water extracted for densely welded tuff using one-dimensional and high-pressure one-dimensional compression

19. Relation of specific conductance to applied axial stress for pore-water sample NWPC-1

20. Diagram showing relative concentrations of cations and anions in pore-water sample NWPC-1 in percent milliequivalents per liter...

21. Graph showing relation of specific conductance to applied axial stress for pore-water sample NWPC-2 ................ 19

22. Diagram showing relative concentrations of cations and anions in pore-water sample NWPC-2 in percent milliequivalents per liter.

23. Graph showing relation of specific conductance to applied axial stress for pore-water sample NWTS

24. Diagram showing relative concentrations of cations and anions in pore-water sample NWTS in percent milliequivalents per liter.

25. Graph showing relation of specific conductance to applied axial stress for pore-water sample NWBT

26. Diagram showing relative concentrations of cations and anions in pore-water sample NWBT in percent milliequivalents per liter.

27. Graph showing relation of specific conductance to applied axial stress for pore-water sample NWCH-1............... 22

28. Diagram showing relative concentrations of cations and anions in pore-water sample NWCH-1 in percent milliequivalents per liter.

29. Graph showing relation of specific conductance to applied axial stress for pore-water sample NWCH-2............... 23

30. Diagram showing relative concentrations of cations and anions in pore-water sample NWCH-2 in percent milliequivalents per liter...

31. Graph showing relation of specific conductance to applied axial stress for pore-water sample NWCH-3............... 24

32. Diagram showing relative concentrations of cations and anions in pore-water sample NWCH-3 in percent milliequivalents per liter .

33. Graph showing relation of specific conductance to applied axial stress for pore-water sample DWTC-1 ............... 25

34. Diagram showing relative concentrations of cations and anions in pore-water sample DWTC-1 in percent milliequivalents per liter

35. Graph showing relation of specific conductance to applied axial stress for pore-water sample DWTC-2 ............... 26

36. Diagram showing relative concentrations of cations and anions in pore-water sample DWTC-2 in percent milliequivalents per liter

37. Graph showing relation of specific conductance to applied axial stress for pore-water sample NWTC-1 ................ 27

38. Diagram showing relative concentrations of cations and anions in pore-water sample NWTC-1 in percent milliequivalents per liter

39. Graph showing relation of specific conductance to applied axial stress for pore-water sample NWTC-2 ................ 28

40. Diagram showing relative concentrations of cations and anions in pore-water sample NWTC-2 in percent milliequivalents per liter

41. Graph showing relation of specific conductance to applied axial stress for pore-water sample NWTC-3 ............... 29

42. Diagram showing relative concentrations of cations and anions in pore-water sample NWTC-3 in percent milliequivalents per liter

43. Graph showing relation of specific conductance to applied axial stress for pore-water sample NWTC-4

44. Diagram showing relative concentrations of cations and anions in pore-water sample NWTC-4 in percent milliequivalents per liter

\section{TABLES}

1. Axial strains from one-dimensional and high-pressure one-dimensional compression tests on tuff cores.

2. Chemical data for pore-water extraction using one-dimensional compression and high-pressure one-dimensional compression 
CONVERSION FACTORS AND VERTICAL DATUM

\begin{tabular}{rll}
\hline Multiply & By & To obtain \\
\hline centimeter $(\mathrm{cm})$ & $3.937 \times 10^{-1}$ & inch \\
gram $(\mathrm{g})$ & $2.205 \times 10^{-3}$ & pound, mass \\
kilopascal $(\mathrm{kPa})$ & $1.450 \times 10^{-1}$ & pounds per square inch \\
kilopascals per second $(\mathrm{kPa} / \mathrm{s})$ & $1.450 \times 10^{-1}$ & pounds per square inch per second \\
meganewton $(\mathrm{MN})$ & $2.248 \times 10^{5}$ & pound, force \\
megapascal $(\mathrm{MPa})$ & $1.450 \times 10^{2}$ & pounds per square inch \\
micrometer $(\mu)$ & $3.937 \times 10^{-5}$ & inch \\
milliliter $(\mathrm{mL})$ & $3.531 \times 10^{-5}$ & cubic foot \\
millimeter $(\mathrm{mm})$ & $3.937 \times 10^{-2}$ & inch \\
\hline
\end{tabular}

Temperature in degrees Celsius $\left({ }^{\circ} \mathrm{C}\right)$ may be converted to degrees Fahrenheit $\left({ }^{\circ} \mathrm{F}\right)$ as follows:

$$
{ }^{\circ} \mathrm{F}=\left(1.8 \times{ }^{\circ} \mathrm{C}\right)+32
$$

Temperature in degrees Fahrenheit $\left({ }^{\circ} \mathrm{F}\right)$ may be converted to degrees Celsius $\left({ }^{\circ} \mathrm{C}\right)$ as follows:

$$
{ }^{\circ} \mathrm{C}=\left({ }^{\circ} \mathrm{F}-32\right) / 1.8
$$

Sea level: In this report, "sea level" refers to the National Geodetic Vertical Datum of 1929 (NGVD of 1929) - a geodetic datum derived from a general adjustment of the first-order level nets of both the United States and Canada, formerly called Sea Level Datum of 1929. 


\title{
The One-Dimensional Compression Method for Extraction of Pore Water from Unsaturated Tuff and Effects on Pore-Water Chemistry
}

\author{
By Jerry D. Higgins, Paul A. Burger, Colorado School of Mines, Golden, Colorado; \\ and In C. Yang, U.S. Geological Survey, Denver, Colorado
}

Abstract

Study of the hydrologic system at Yucca Mountain, Nevada, requires extraction of porewater samples from unsaturated tuff bedrock. Two generations of compression cells have been designed and tested for extracting representative, unaltered pore-water samples from unsaturated tuff cores. The one-dimensional compression cell has a maximum compressive stress rating of $552 \mathrm{MPa}$. Results from 86 tests show that the minimum degree of saturation for successful extraction of pore water was about 14 percent for nonwelded tuff and about 61 percent for densely welded tuff. The high-pressure, one-dimensional compression cell has a maximum compressive stress rating of $827 \mathrm{MPa}$. Results from 109 tests show that the minimum degree of saturation for successful extraction of pore water was about 7.5 percent for nonwelded tuff and about 34 percent for densely welded tuff.

Geochemical analyses show that, in general, there is a decrease in ion concentration of pore waters as extraction pressures increase. Only small changes in pore-water composition occur during the one-dimensional extraction test.

\section{INTRODUCTION}

The unsaturated tuff at Yucca Mountain, Nevada, is being evaluated for the U.S. Department of Energy with assistance from the U.S. Geological Survey (USGS) as a potential site for a high-level radioactive-waste repository. Work being conducted by the USGS includes a hydrochemical study to assess characteristics of the hydrologic system such as ground-water traveltime, direction of flow, recharge and source relations, and types and magnitudes of chemical reactions in water in the unsaturated zone. This hydrochemical information will also be used in the study of the dispersive and corrosive effects of unsaturated-zone water on radioactive-waste storage canisters. A method of extracting pore water from nonwelded and welded tuffs needed to be developed to provide pore water for chemical and isotopic analyses. New mechanical compression methods and equipment have been designed to obtain representative samples of pore water from tuffs that have small initial moisture contents.

\section{Purpose and Scope}

This paper describes (1) the design of equipment and validation of experimental laboratory procedures for extracting representative samples of unaltered pore water from welded and nonwelded, unsaturated tuffs from on or near the Yucca Mountain, Nevada, site; and (2) the effects of the extraction method on the original pore-fluid composition. These procedures include the use of two generations of onedimensional compression cells that were specifically designed and fabricated for this investigation.

A total of 86 tests were completed using a one-dimensional compression cell (first-generation design), and 109 tests were completed using a highpressure, one-dimensional compression cell (second generation design). These tests were used to determine the optimum stress and duration for porewater-extraction tests on welded and nonwelded tuff core samples. Sequential pore-water samples were collected from single tests on 13 core samples to evaluate potential changes in water chemistry due to the testing process.

Three groups of factors were considered in the development of the testing methods:

1. Factors that govern the amount and rate of compression of the sample, including tuff 
mineralogical composition, texture, and degree of welding;

2. Factors that could cause alteration of the pore-water chemistry during compression, including tuff mineralogical composition, duration and rate of loading, potential for core temperature increase, and exposure time of pore water to newly created mineral surfaces; and

3. Water volume required for chemical analysis.

\section{Acknowledgments}

The authors wish to thank the Bureau of Reclamation and Mr. Joseph Prizio of that agency for their substantial contribution to the design and construction of the one-dimensional compression cells and their interest and support in development of the testing procedures.

\section{Location of Sample Sites}

Core specimens used for pore-water extraction were collected from three sources: (1) vertical boreholes on and in the vicinity of Yucca Mountain, (2) horizontal boreholes in the U12g tunnel complex (G-Tunnel) at Rainier Mesa, and (3) laboratory cores cut from blocks of blast rubble from G-Tunnel. These sample sites are located on or adjacent to the Nevada Test Site (NTS), which is about $105 \mathrm{~km}$ northwest of Las Vegas, Nevada (fig. 1).

\section{General Geologic Relations at the Nevada Test Site}

Most of the tuffs present at the NTS and Yucca Mountain were erupted from the Timber Mountain-Oasis Valley caldera complex between 9 and 16 million years ago. The caldera complex is located in, and adjacent to, the northwest part of the NTS (Lipman and others, 1966 and Byers and others, 1976). Simplified stratigraphic columns of Yucca Mountain and Rainier Mesa are presented in figure 2. Pore-water-extraction tests were conducted on the following lithologic units from Yucca Mountain (all from the Paintbrush Group): Tiva Canyon Tuff, Yucca Mountain Tuff, Pah Canyon Tuff, and Topopah Spring Tuff. From G-Tunnel (U12g) in Rainier Mesa, pore water was extracted from the Grouse Canyon Tuff and

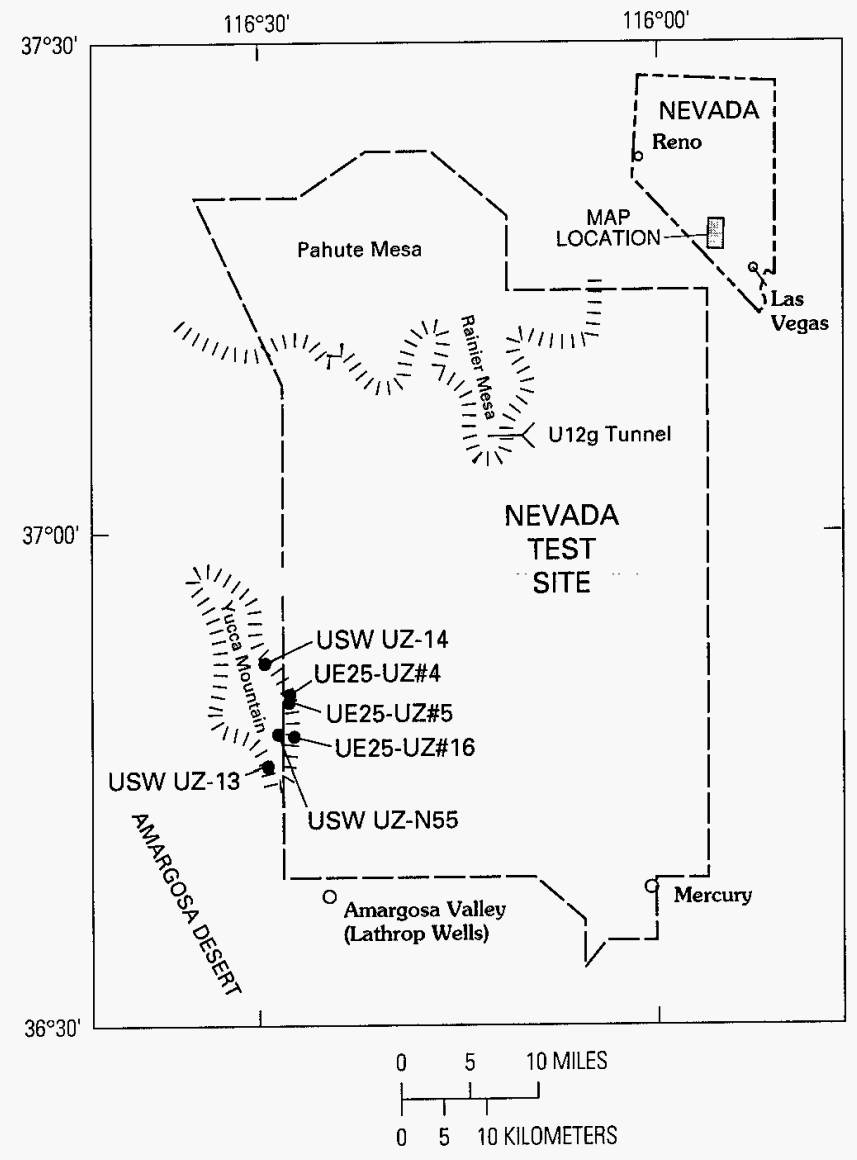

Figure 1. Location of sampling sites on and near the Nevada Test Site.

Tunnel bed 5 of the Belted Range Group. Sample cores from these formations included nonwelded, partially welded, and densely welded tuffs.

\section{REVIEW OF PREVIOUS WORK}

Compression methods have been used for the study of both natural and anthropogenic solid-phase materials and pore-water extraction. Investigations of sediment diagenesis (especially the compaction of clays) have used compression methods extensively. Rieke and Chilingarian (1974) and Singer and Müller (1983) presented summaries of compression methods in the study of sediment diagenesis. Manheim (1974) listed many of the types of squeezing devices used for compressing ocean sediment for the study of interstitial water. Barneyback and Diamond (1981) used a high-pressure device to extract pore fluid from hardened cement pastes to study the reaction between 
YUCCA MOUNTAIN

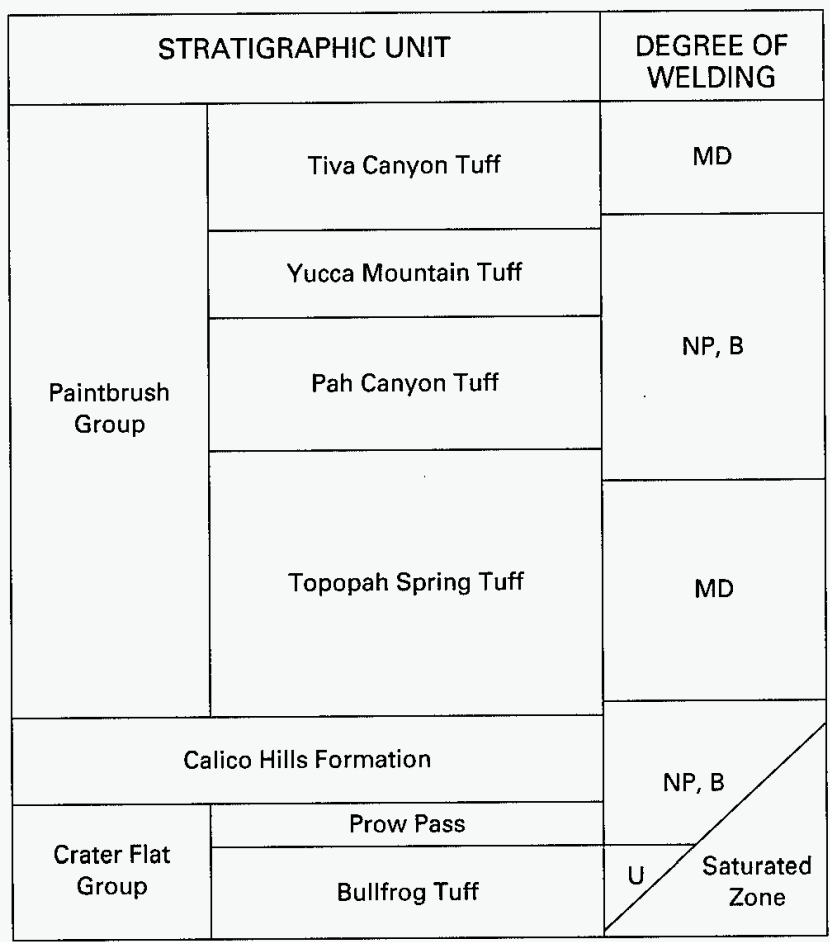

RAINIER MESA

\begin{tabular}{|c|c|c|}
\hline \multicolumn{2}{|c|}{ STRATIGRAPHIC UNIT } & DEGREE OF \\
\hline $\begin{array}{c}\text { Timber } \\
\text { Mountain } \\
\text { Group }\end{array}$ & Rainier Mesa Tuff & MD \\
\hline \multirow{5}{*}{$\begin{array}{l}\text { Paintbrush } \\
\text { Group }\end{array}$} & Bedded tuff & $N P, B$ \\
\hline & Tiva Canyon Tuff & MD \\
\hline & Bedded tuff & $N P, B$ \\
\hline & Stockade Wash Tuff & NP \\
\hline & Bedded tuff & $N P, B$ \\
\hline \multirow{6}{*}{$\begin{array}{c}\text { Belted Range } \\
\text { Group }\end{array}$} & Grouse Canyon Tuff & MD \\
\hline & Tunnel bed 5 & $N P, B$ \\
\hline & Tunnel bed 4 & $N P, B$ \\
\hline & Tunnel bed 3 & $\mathrm{NP}, \mathrm{B}$ \\
\hline & Tunnel bed 2 & $N P, B$ \\
\hline & Tunnel bed 1 & $N P, B$ \\
\hline
\end{tabular}

Figure 2. Generalized geologic relations at Yucca Mountain and Rainier Mesa. [MD, moderately to densely welded; NP, nonwelded to partially welded; $B$, bedded; $U$, undifferentiated; thicknesses not to scale; modified from Gibbons and others (1963), Montazer and Wilson (1984), and Zimmerman and Finley (1987)]

pore fluid and support steel in reinforced concrete. This device was capable of applying a maximum axial stress of about $550 \mathrm{MPa}$ to a sample that was about $45 \mathrm{~mm}$ in length and $53 \mathrm{~mm}$ in diameter. L.J. Struble (National Institute for Standards and Technology, oral commun., 1988) and D.M. Roy (Pennsylvania State University, oral commun., 1988) used similar, but slightly modified devices in concrete research.

Three publications that describe pore-water extraction from unsaturated rock by compression have a direct bearing on the research presented in this paper. Work done by Dropek and Levinson (1975) examined pore-water extraction from nonwelded tuffs from Rainier Mesa using triaxial compression. The use of triaxial compression for pore-water extraction from nonwelded, Yucca Mountain tuffs was extended and modified by Yang and others (1988). This study describes modifications made to a standard, commercially available, triaxial compression rock cell with vented pore-pressure platens, which were used for transferring extracted water to external syringes. The triaxial cell could accommodate core samples that were between 98 and $113 \mathrm{~mm}$ in length and $61 \mathrm{~mm}$ in diameter. These modifications included:

(1) redesigned, thicker end caps to withstand large axial pressures during long-duration tests, (2) Teflonwrapped test specimens to reduce the risk of contamination during pore-water extraction, and (3) collection of expelled water in syringes to eliminate contact between expelled water and the atmosphere.

Mower and others (1994) modified the triaxial cell and the test procedure to improve upon the previous study. After the test core had been loaded to the maximum axial and confining stress of $193 \mathrm{MPa}$ and $68 \mathrm{MPa}$, respectively, dry nitrogen gas (greater than 99.999 percent pure) was injected through the upper platen. The injection of nitrogen gas forced additional pore water out of the core and through the bottom platen, if the core had been compressed enough to reach 100 percent saturation.

Yang and others (1988) found that the minimum initial moisture content for successful pore-water extraction from nonwelded tuff cores was about 13 percent, and the initial degree of saturation was 
about 42 percent. (Moisture content is the mass of water divided by the mass of solids multiplied by 100 . Degree of saturation is the volume of water divided by the volume of voids multiplied by 100 .)

Mower and others (1994) verified these findings and were able to improve the success with nitrogen gas injection. Using gas injection reduced the minimum initial moisture content for successful porewater extraction for similar rocks to about 11 percent and reduced the required initial saturation to about 24 percent. No pore water could be extracted from welded tuffs because of the limited maximum stress capacity of the triaxial cell.

These two studies were designed to expel water from rocks through compression of the voids without failing a sample by shear. As a sample is loaded, pores collapse, reducing the void space. Once the void space has been reduced to the point that all interconnected voids are fully saturated (degree of saturation is 100 percent), any additional load will be taken up instantaneously by the relatively incompressible water in the voids. This causes a hydraulic gradient within the rock that forces pore water to flow out of the sample. For this test to be successful, the stress that is applied to a rock sample must exceed the internal strength of the rock skeleton and the voids must collapse enough to cause a fully saturated condition in the rock.

The two previous studies found that extraction of pore water by compression of partially saturated nonwelded tuff cores is feasible. However, many of the tuffs that compose Yucca Mountain are partially or densely welded and have smaller porosities and moisture contents than the nonwelded tuffs previously tested (Montazer and Wilson, 1984). The triaxial cell used did not have the load capacity needed to generate enough strain for collapsing the void spaces to expel water. Therefore, new compression equipment was required for the high-strength rocks.

\section{SAMPLE HANDLING AND PREPARATION}

Procedures used in sample collection, sealing, transportation, storage, and preparation for testing can have an effect on the volume and ionic composition of the extracted pore water. All aspects of these procedures were designed to maintain original core moisture conditions so as to minimize the effects of these activities on pore-water composition and volume.

Cores from vertical boreholes on Yucca Mountain and from horizontal boreholes in G-Tunnel were collected using conventional air-coring methods. Rubble blocks from G-Tunnel were generated by drift excavation using powder blasting explosives. (Blast explosive holes were drilled with air in nonwelded tuff and with water in densely welded tuff.) Rubble blocks ranged in size from $20 \mathrm{~cm} \times 20 \mathrm{~cm} \times 20 \mathrm{~cm}$ to $60 \mathrm{~cm} \times$ $60 \mathrm{~cm} \times 40 \mathrm{~cm}$. After sealing, transportation, and storage, the blocks were air-cored. All cores used in pore-water-extraction testing had a nominal diameter of $61 \mathrm{~mm}$.

Three sealing methods were used after cores were collected to preserve original moisture conditions: aluminum foil and beeswax, split PVC (polyvinyl chloride) pipe, and Lexan (polycarbonate) liner.

Sealed cores and rubble blocks collected at the NTS were transported to the Denver Federal Center in an air conditioned van. Cores and blocks were stored in refrigerated and humidity controlled lockers maintained at 4 to $10^{\circ} \mathrm{C}$ to inhibit evaporation.

\section{Core Sample Preparation}

The objective of the sample preparation procedure was to produce a test specimen of the appropriate length while minimizing exposure of the core to evaporation and heating. A gas-cooled diamond saw was used to cut cores to the required length for testing. The saw was a standard $46-\mathrm{cm}$ water-cooled rock saw modified to use compressed dry air or nitrogen (or any bottled gas) as a coolant. A 3-mm orifice was mounted about $25 \mathrm{~mm}$ below the cutting deck to direct the gas coolant at the cutting surface of the blade. The gas served to flush cuttings from the blade surface and to cool the blade without blowing directly on the core during cutting. A delivery pressure of about $0.7 \mathrm{MPa}$ was adequate to prevent densely welded tuff cores from heating more than about $3^{\circ} \mathrm{C}$ during cutting (nonwelded tuff cores usually showed no heating during cutting).

Nonwelded tuff cores were prepared at about 1 minute per cut; welded tuff cores required between 3 and 5 minutes per cut depending on the degree of welding and the condition of the cutting surface of the blade. 
Samples were cut to produce test specimens that had smooth end surfaces perpendicular to the long axis of the core. The terms "smooth" and "perpendicular" as used here are only approximations of the test specimen requirements for precise measurements of rock strength properties.

After the cores were cut to the appropriate length, the test specimens were sealed in plastic film, aluminum foil, duct tape, and beeswax and stored in a refrigerated locker until tested. Pore-water-extraction tests were conducted on most specimens within 24 hours of cutting.

End pieces from cut cores were dried to a constant weight at 100 to $105^{\circ} \mathrm{C}$ to determine an approximate moisture content for the core (American Society for Testing and Materials, 1988a). Also, the moisture content of the cut ends was occasionally checked by drying the compressed core and backcalculating the initial moisture content. Good agreement between moisture content values was obtained if the mass of the dried, cut ends was at least $100 \mathrm{~g}$.

\section{Water Sample Handling}

Pore-water samples were collected at different loading increments to evaluate the efficiency of porewater extraction and to determine chemical changes in pore water from the loading technique. Samples were collected in disposable, sterile, plastic syringes and were filtered through $0.45-\mu \mathrm{m}$ disposable filters before storage. Immediately after filtration, the $\mathrm{pH}$ and specific conductance of each water sample were measured using compact $\mathrm{pH}$ and specific conductance meters manufactured by Horiba, Inc.; the three to four drops of water required for each measurement were not recoverable. Replicate $\mathrm{pH}$ and specific conductance measurements were made when the water sample volume (before filtration) was more than $3 \mathrm{ml}$. After completing these measurements, the remaining water was stored in tightly-capped polyethylene bottles; the bottle caps were sealed using two wraps of plastic tape to further minimize leakage of water vapor during storage. Sample bottles were placed in refrigerated storage at $9^{\circ} \mathrm{C}$ until delivery to the contract laboratory for chemical analysis of dissolved ionic chemistry. Sample handling, including filtration and $\mathrm{pH}$ and specific conductance measurements, normally used a total of $0.5 \mathrm{ml}$ of the pore-water sample.
The minimum water volume required for a sample depends on several factors: the type of analysis to be done, the type of instrument used, the laboratory making the analysis, and the measurement precision required for each analysis. The type of analysis to be made and the type of instrument used for the analysis affect the minimum water volume because each analysis technique and specific instrument has a minimum water volume requirement. Each laboratory also has its own unique equipment setup and, so, has its own minimum sample volume requirements. Finally, the required level of precision for each analysis adds another constraint on the minimum water volume.

Based on all of the above considerations, the minimum water sample volume sent to the laboratory for a complete analysis was $2.0 \mathrm{ml}$. The target water sample volume (before filtration) was $3.0 \mathrm{ml}$; the target volume included $0.5 \mathrm{ml}$ for water sample handling and $0.5 \mathrm{ml}$ for contingencies.

\section{PORE-WATER EXTRACTION BY ONE- DIMENSIONAL COMPRESSION}

\section{Design of One-Dimensional Pore-Water- Extraction Cell}

Two generations of one-dimensional porewater-extraction cells were designed and fabricated for this study. The design of the first-generation onedimensional compression cell was based on compression cells used in concrete research (Barneyback and Diamond, 1981) with major modifications. The primary design objectives were for a system that: (1) avoided the inherent difficulties of the triaxial system, such as membrane leakage and limited maximum stress; (2) operated simply; and (3) operated efficiently over a large range of stresses so that pore fluids could be extracted from samples of both welded and nonwelded tuffs.

The one-dimensional compression cell is shown schematically in figure 3 . It was the first cell to be designed and tested, and was the simpler, less expensive, and lower pressure capacity of the two. It was built and tested to verify whether this type of design would perform significantly better than the triaxial cell and with fewer operational problems. 


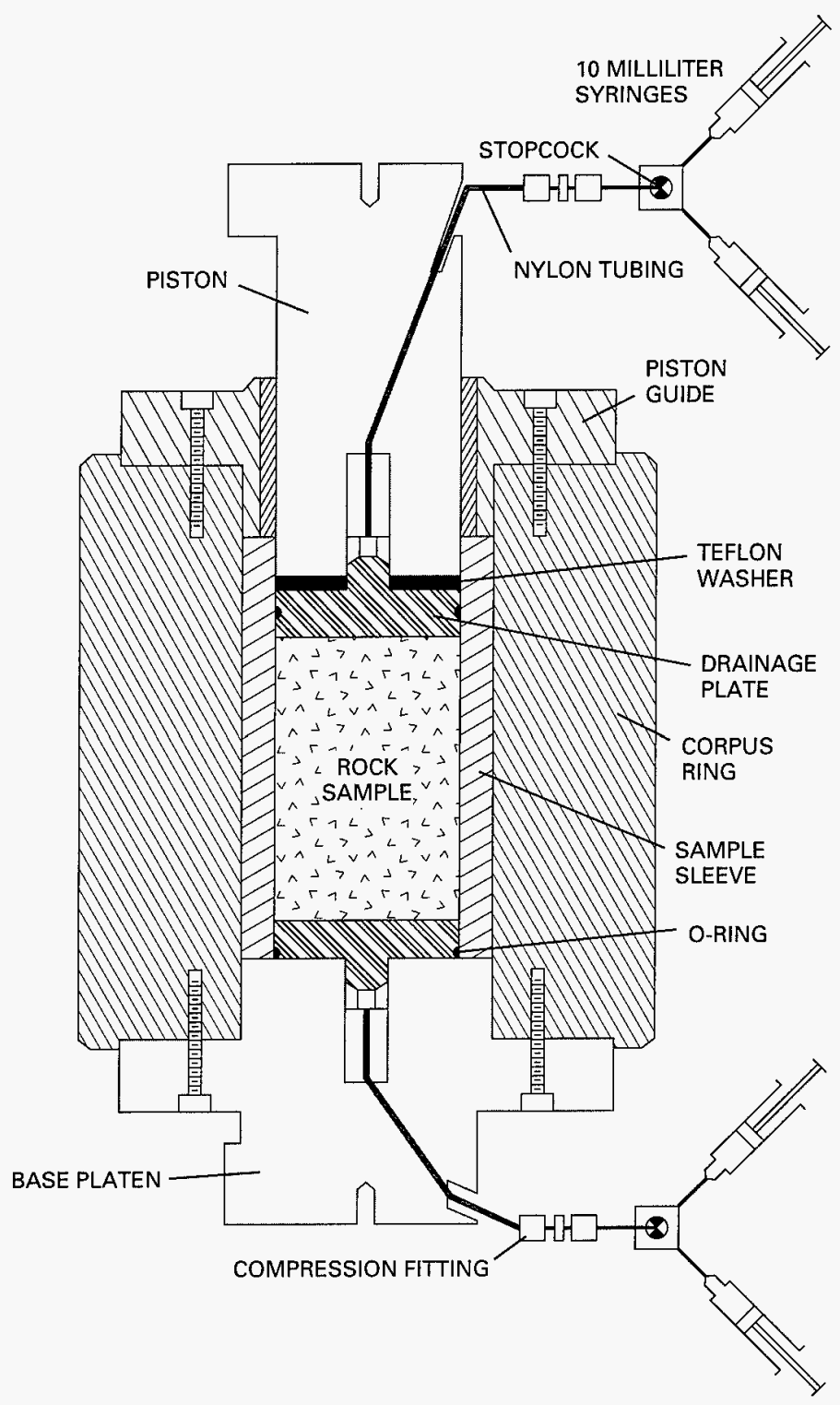

Figure 3. One-dimensional compression cell. 
The major components, made of 4340-alloy steel, are the corpus ring, base platen, piston, and piston guide. These components were heat treated to a yield strength of $1030 \mathrm{MPa}$. The sample sleeve and drainage plates are formed from Monel K500 nickel alloy and were age-hardened to a yield strength of $690 \mathrm{MPa}$. The core is wrapped in a Teflon sheet and confined in the sample sleeve. The drainage plates have holes for pore-water drainage and are connected by nylon tubing to syringes for gas and water collection. The sample chamber is sealed by use of O-rings and a Teflon washer between the upper drainage plate and the piston. This closed system prevents contact between expelled pore water and the atmosphere. The one-dimensional compression cell has a maximum compressive stress rating of $552 \mathrm{MPa}$. This maximum rating is based on the yield strength of the steel used in the cell and on the thickness of the corpus ring.

The one-dimensional compression cell can accommodate cores that are $61 \mathrm{~mm}$ in diameter and as long as $110 \mathrm{~mm}$. Core samples shorter than about $55 \mathrm{~mm}$ can be compressed by inserting steel spacers beneath the base drainage plate and effectively increasing the specimen length. The practical minimum specimen length is controlled by the amount of water in the test sample; the specimen must be of sufficient size to produce an adequate volume of water for analysis.

Two different types of drainage plates were used during one-dimensional compression testing: grooved and smooth (fig. 4). The grooved drainage plates have the same pattern of grooves in the face that contacts the core as the platens used in the triaxial compression cell. Extracted water collects in the grooves and is directed to a central port that allows the water to pass to the rear of the plate. Smooth drainage plates have a circumferential drainage channel that leads to two ports that, in turn, transmit the collected water from the edge of the plates through the inside to a central exit point at the rear of the plates. Compression fittings connect the rear of either style drainage plate to the nylon tubing that transmits expelled water out of the one-dimensional compression cell into collection syringes. During one-dimensional compression testing, grooved drainage plates were used after initial tests demonstrated that smooth drainage plates tended to clog if the Tefion wrap on the specimen slipped any appreciable amount.
GROOVED DRAINAGE PLATE
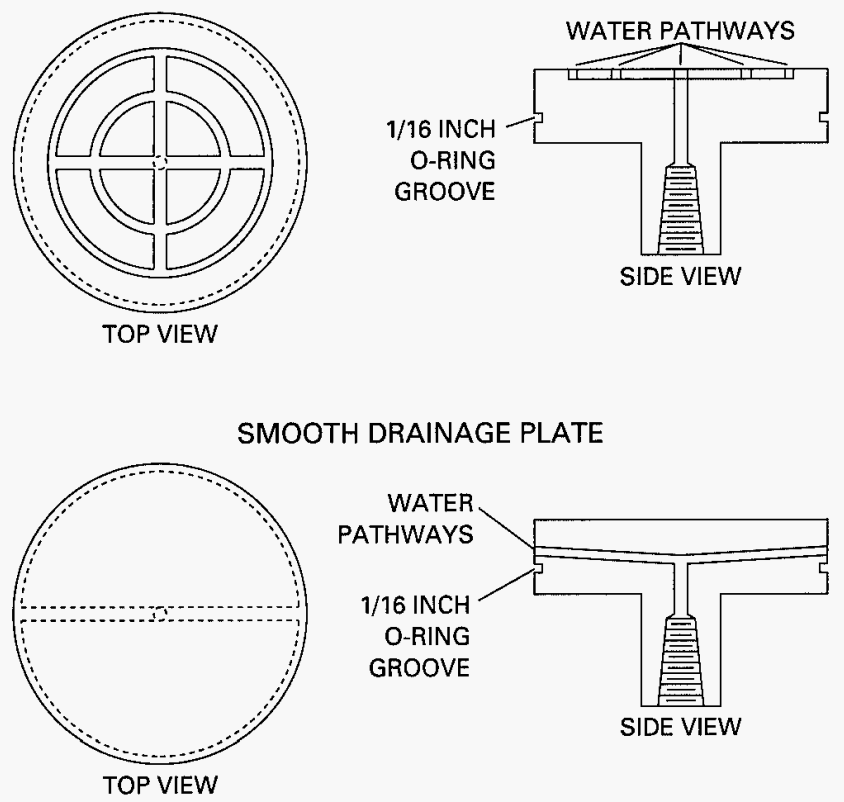

Figure 4. Drainage plates used in one-dimensional compression cell.

\section{Operation of One-Dimensional Pore- Water-Extraction Cell}

A load frame capable of applying at least $1.7 \mathrm{MN}$ is necessary to generate the $552 \mathrm{MPa}$ maximum axial stress. All of the one-dimensional compression tests for this study were done using a load frame that had a capacity of $2.7 \mathrm{MN}$.

The initial assembly of the one-dimensional compression cell begins with the preparation of the drainage pathways. Nylon tubing and compression fittings are attached to each drainage plate. The base drainage plate and base platen are then connected to the corpus ring. The test core is jacketed in one to two wraps of Teflon and is inserted into the sample sleeve. Teflon is used as a chemically inert barrier between the sample and the metal sample sleeve to reduce the potential for chemical reactions between the expelled pore water and the sample sleeve. The Teflon wrap allows the sample to compress without adhering to the sample sleeve and facilitates extrusion of the sample after a test. The top drainage plate, 3-mm thick Teflon seal washer, piston guide, and piston are then inserted into the top of the cell. The exterior compression fittings are connected to the nylon tubing, and the stainless-steel tubing and syringes are attached for gas and water collection. A two-way stopcock valve is 
located upstream of the syringes so that after one syringe fills, flow can be diverted to another syringe.

Initially, a seating load of about 7 to $9 \mathrm{kN}$ is applied to the piston to ensure good metal-to-metal contacts between bearing components of the cell. The core is then loaded to the first stress level of $69 \mathrm{MPa}$ at a rate of $69 \mathrm{kPa} / \mathrm{s}$. Loading continues in seven increments of $69 \mathrm{MPa}$ (at the same loading rate) until the final stress level of $552 \mathrm{MPa}$ is reached; a loading history is shown in figure 5. A sequence of load steps was chosen for four reasons: (1) to distribute a number of steps over the entire load range, (2) to make the magnitude of the individual steps approximately equal to the size of the steps used in the early triaxial compression testing studies, (3) to allow pore-water sampling at various pressures for evaluation of potential pore-water chemistry changes as pressure increases, and (4) to allow the rock skeleton time to undergo maximum deformation. The loading rate was selected on the basis of rates recommended for determination of strength properties (American Society for Testing of Materials, 1988b). Water samples are taken when adequate volumes of water (greater than $3 \mathrm{ml}$ ) are collected in the syringes.

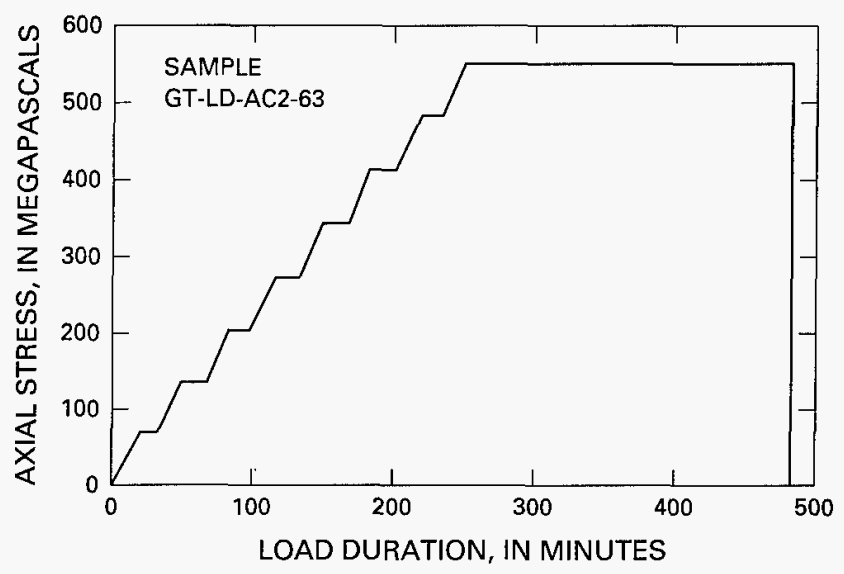

Figure 5. Typical loading history for one-dimensional compression pore-water extraction test.

At the maximum axial stress, after water expulsion (if any) has ceased and the core has stopped compacting, additional pore water may be extracted by injecting dry nitrogen gas (greater than 99.999 percent pure) into the pore space and by forcing out pore water. Gas injection will expel pore water if compression has caused the rock structure to compact and create a totally saturated sample.
Nitrogen pressure that ranged from 1.4 to $10.3 \mathrm{MPa}$ was applied through the piston from a nitrogen tank.

The test core is unloaded after pore-water extraction is completed. Due to the large stresses used during one-dimensional compression, the core is firmly seated in the sample sleeve and must be pressed out using the load frame. A steel cylinder that is slightly smaller in diameter than the core is used in conjunction with a support ring to press the core sample out of the sample sleeve. After the core has been removed, the remaining components and fittings may be disassembled. Used syringes and nylon tubing are discarded; all components that contacted the core or the extracted water are washed, rinsed in deionized water, and thoroughly dried.

The first-generation one-dimensional compression cell was built primarily to extract pore water from nonwelded tuffs and to prove the system application to this specific project. The cell proved to be a more successful design than the modified triaxial system with respect to extracting pore water from tuff cores with low moisture contents and ease of use. As will be discussed in detail below, pore water was extracted successfully from nonwelded and some partially welded and densely welded tuff cores.

\section{Design of the High-Pressure One- Dimensional Compression Cell}

The validation of the first-generation onedimensional compression cell and method made it possible to consider designing a high-pressure onedimensional compression cell that would have the capacity to compact and extract pore water from relatively high-strength welded tuffs. The design of a test cell that could withstand pressures significantly higher than the first-generation cell is much more complicated than the design of common equipment in use in rock or soil engineering. Therefore, specialized expertise was required to design a safe, functional system. The Bureau of Reclamation designed the system with advice and review by a consultant with experience in design of high-pressure cells.

The conceptual design of the high-pressure onedimensional compression cell is based on the first generation cell, but modifications in material and configuration of components were necessary to allow high axial pressures. The cell is shown schematically in figure 6. The major components of the cell (inner 


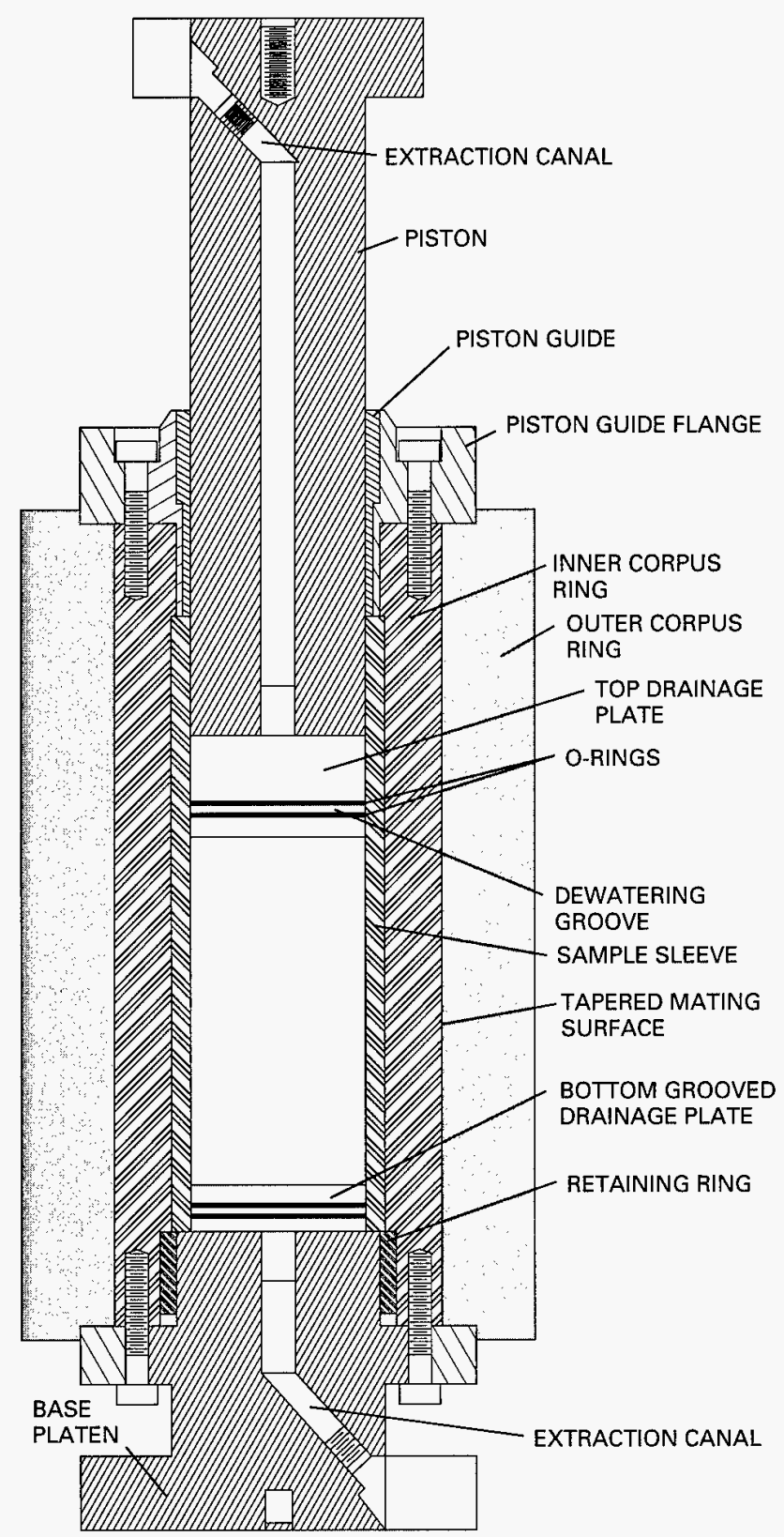

Figure 6. High-pressure one-dimensional compression cell. 
and outer corpus rings, sample sleeve, grooved drainage plates, base platen, piston, and retaining ring) are constructed of 250 maraging steel. The piston guide flange is 4340 steel and the piston guide is bronze. The inner and outer corpus rings are pushed together under pressure and are in contact along a tapered mating surface. Similar to the first cell design, the core is wrapped in a Teflon sheet and confined in the sample sleeve. The drainage plates have holes for pore-water transmittal and are connected by nylon tubing to syringes for gas and water collection. The sample chamber is sealed by use of O-rings around the drainage plates, which provides a closed system and prevents contact between expelled pore water and the atmosphere. This system has a maximum compressive stress rating of $827 \mathrm{MPa}$, which is based on the yield strength of the steel used in the cell and on the thickness of the corpus rings.

The high-pressure one-dimensional compression cell can accommodate cores that are $61 \mathrm{~mm}$ in diameter and as long as $110 \mathrm{~mm}$. The practical minimum specimen length is controlled by the amount of water in the test sample; the specimen must be of sufficient size to produce an adequate volume of water for analysis.

\section{Operation of the High-Pressure One- Dimensional Compression Pore-Water Extraction Cell}

The initial assembly of the high-pressure onedimensional compression cell is similar to the procedure for the one-dimensional system discussed above. A seating load of about 7 to $9 \mathrm{kN}$ is applied to the piston to ensure good metal-to-metal contacts between bearing components of the cell. The core is then loaded to the first stress level of $103.4 \mathrm{MPa}$ at a rate of $69 \mathrm{kPa} / \mathrm{s}$. Loading continues in eight increments of 103.4 MPa (at the same loading rate) until the final stress level of $827 \mathrm{MPa}$ is reached. A typical loading history diagram is shown in figure 7. The sequence of load steps is similar to the onedimensional compression system, but with an increased maximum pressure. Once maximum axial pressure is reached, the procedure for injecting dry nitrogen gas to acquire additional pore water is the same as explained previously.

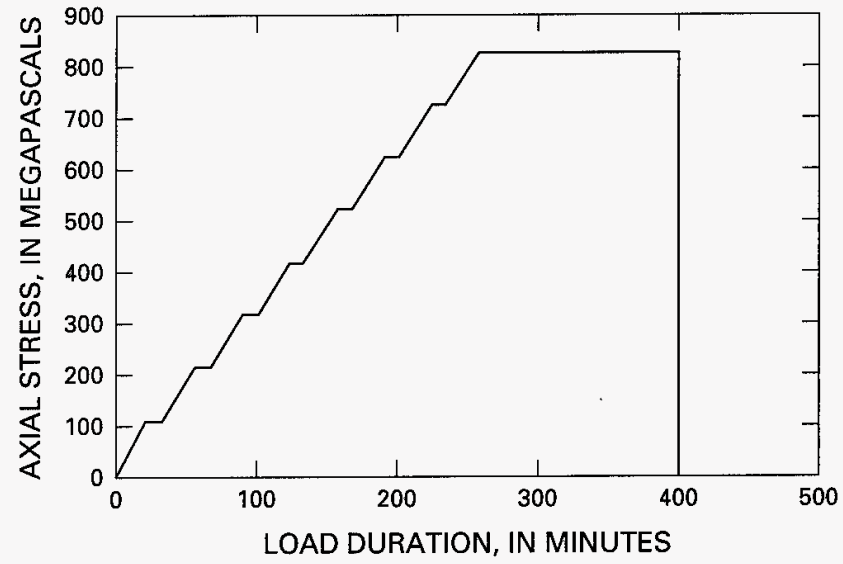

Figure 7. Typical loading history for high-pressure onedimensional compression pore-water extraction test.

\section{Results of Compression Tests}

A tabulation of ranges for axial strains obtained for 86 one-dimensional compression tests and 109 high-pressure one-dimensional compression tests is included in table 1 . The wide range in strains obtained illustrates a wide range of rock strength within each of the three categories of tuff welding. This, in turn, causes variation in compaction of rock structure and in success of extracting pore water from these rock types.

Table 1. Axial strains from one-dimensional and highpressure one-dimensional compression tests on tuff cores [NW, nonwelded; PW, partially welded; DW, densely welded]

\begin{tabular}{ccc}
\hline Welding & $\begin{array}{c}\text { Range of strain } \\
\text { (percent) }\end{array}$ & $\begin{array}{c}\text { Average strain } \\
\text { (percent) }\end{array}$ \\
\hline \multicolumn{3}{c}{ One-dimensional compression } \\
NW & $21-62$ & 37 \\
PW & $18-45$ & 22 \\
DW & $6-13$ & 10 \\
\multicolumn{4}{c}{ High-pressure one-dimensional compression } \\
NW & $11-58$ & 41 \\
PW & $14-45$ & 28 \\
DW & $6-40$ & 19 \\
\hline
\end{tabular}

A representative axial stress-axial strain curve for a nonwelded tuff core tested using onedimensional compression is illustrated in figure 8. A similar curve for one-dimensional compression of a densely welded tuff core is presented in figure 9 . The short segments of the curves that indicate increasing 
axial strain at a constant axial stress represent creep as the core is held at various levels of axial stress.

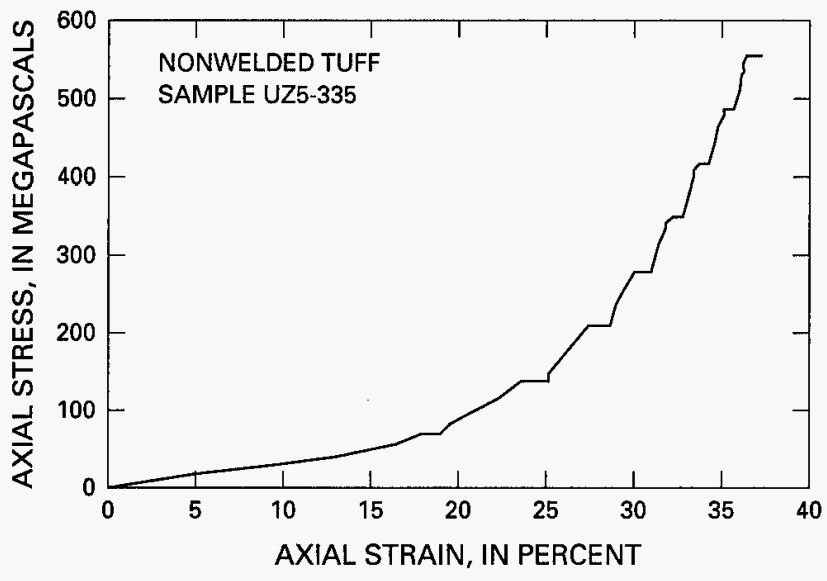

Figure 8. Typical relation between axial stress and axial strain for one-dimensional compression of a nonwelded tuff core.

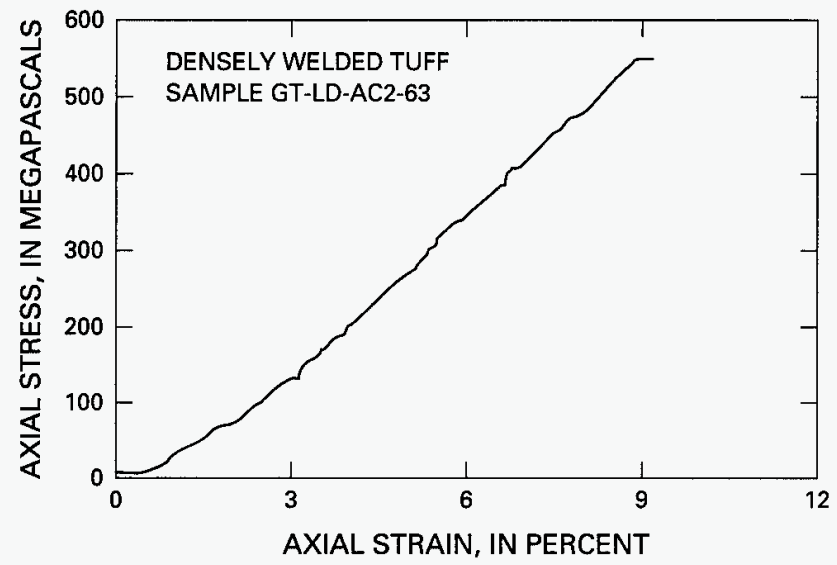

Figure 9. Typical relation between axial stress and axial strain for one-dimensional compression of a densely welded tuff core.

Plots of degree of success versus degree of saturation for one-dimensional compression and highpressure one-dimensional compression tests on nonwelded, partially welded, and densely welded tuff cores are shown in figures 10,11 , and 12 , respectively. (Degree of success is calculated as the total volume of water extracted divided by the total volume of water in the test specimen.) The considerable scatter of data points is expected as a result of the wide range in axial strains experienced for these tests. The plots show minimum values of saturation from which pore water has been extracted and ranges of saturations that porewater extraction is likely to be successful.

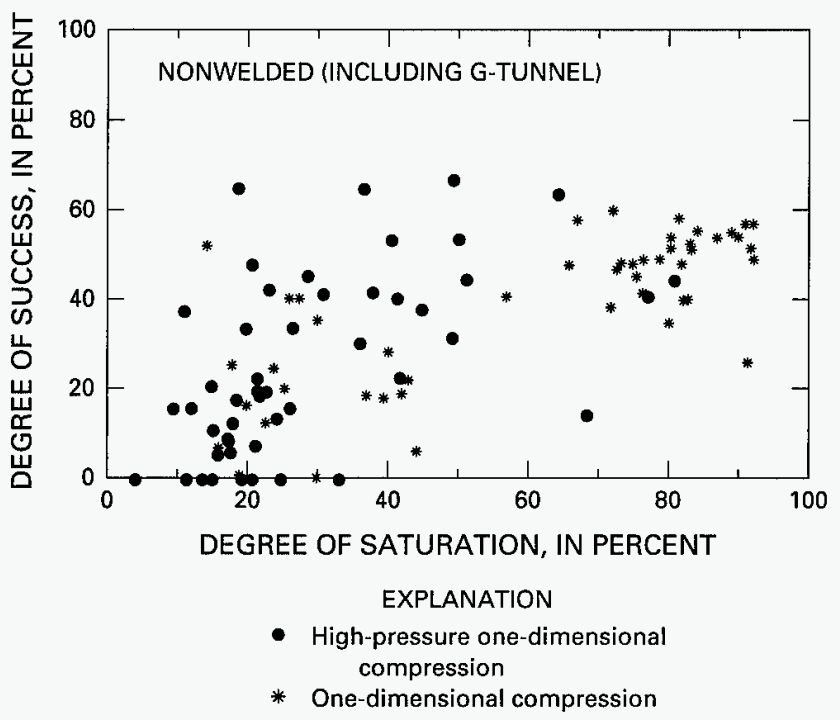

Figure 10. Relation between degree of saturation and degree of success for nonwelded tuff using one-dimensional and high-pressure one-dimensional compression.

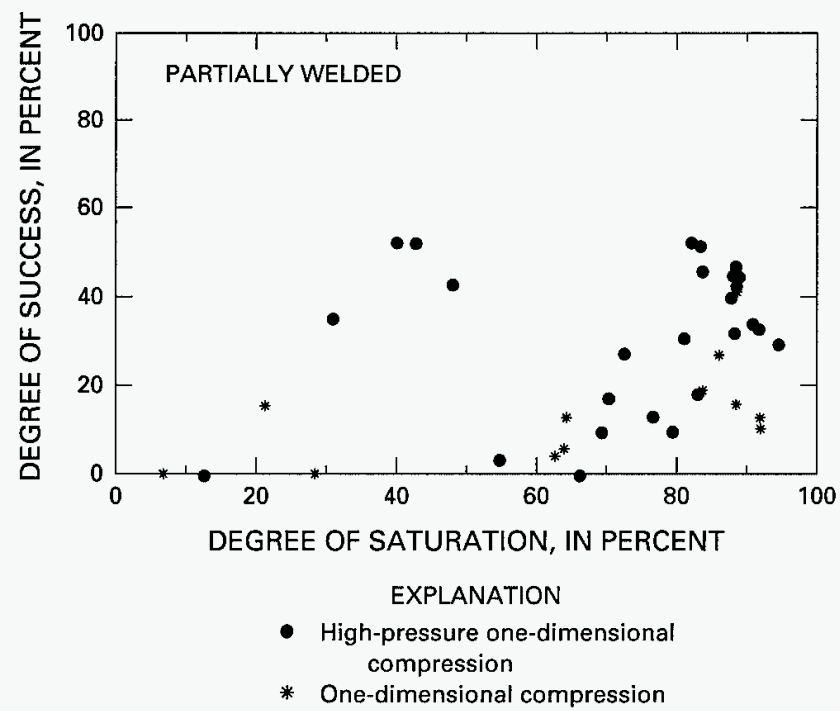

Figure 11. Relation between degree of saturation and degree of success for partially welded tuff using one-dimensional and high-pressure one-dimensional compression. 


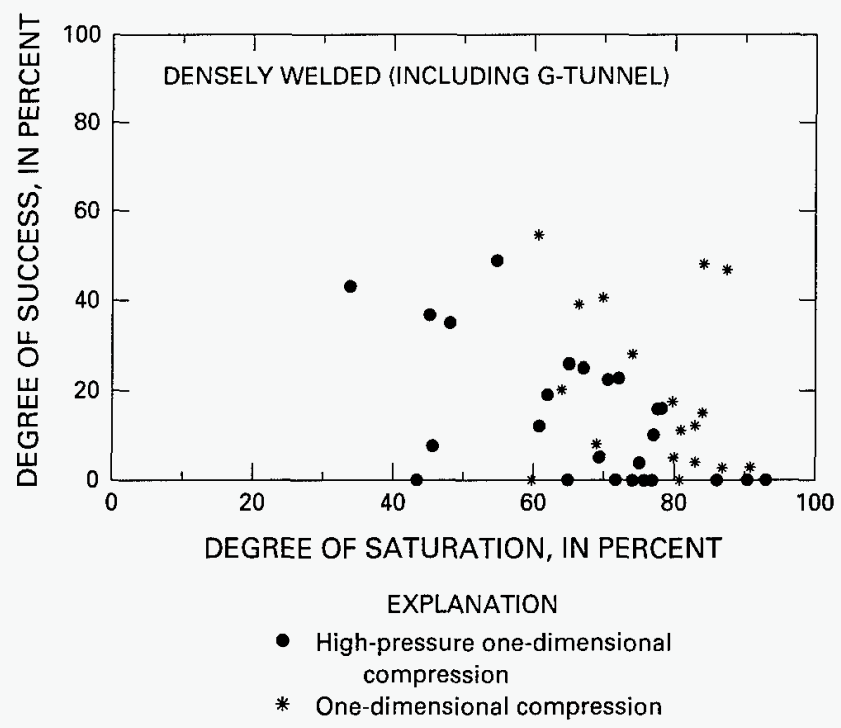

Figure 12. Relation between degree of saturation and degree of success for densely welded tuff using one-dimensional and high-pressure one-dimensional compression.

For one-dimensional compression, the minimum degree of saturation for successful porewater extraction was about 14 percent for nonwelded tuff (fig. 10) and about 61 percent for densely welded tuff (fig. 12). For partially welded tuff (fig. 11), the minimum saturation for pore-water extraction was about 21 percent; however, only three samples were tested at saturations less than 60 percent and only one of those three produced pore water.

High-pressure one-dimensional compression tests resulted in a minimum initial saturation for successful pore-water extraction of about 7.5 percent for nonwelded tuff, about 31 percent for partially welded tuff, and about 34 percent for densely welded tuff.

Water content and volume of water extracted have been used extensively in previous work. Therefore, figures 13,14, and 15 (plots degree of success versus moisture content) and figures 16,17 , and 18 (plots volume of water extracted versus degree of saturation) are included for reference purposes.

An examination of figures 10 through 18 supports some general conclusions. Figures 10, 13, and 16 illustrate that both the one-dimensional and high-pressure one-dimensional systems perform well on nonwelded tuff samples. Figures 11, 12, 14, 15, 17, and 18 illustrate that the high-pressure onedimensional compression system usually results in larger extraction success (larger volumes of water extracted) for partially and densely welded tuffs than the one-dimensional compression system. Figures 10 through 18 show that cores that have a larger initial degree of saturation (moisture content) produce more water from compression than cores that have a smaller initial saturation (moisture content). The exceptions to this statement are when rock compressive strength is high enough that adequate deformation is not obtained to cause a pore-water pressure gradient out of the sample.

Two variations of the high-pressure onedimensional compression test described above have been attempted. These include a "quick" test and a "chips" test. The former is an effort to shorten the test time and the latter is an effort to deal with broken or odd-size core. Results are inconclusive since only a limited number of each of these tests have been completed; however, results have been promising enough to justify descriptions of each test.

The quick test method is identical to the staged test described above (same rate of loading) without waiting for compaction of the sample. It has been observed in many rocks that rapid loading causes a rock to exhibit a higher compressive strength (undergo less deformation) than when loaded at a slow rate. Based on five comparisons of quick loading versus staged loading of nonwelded tuff cores, strains are similar for both methods and pore-water extraction success should be similar. Nine tests on partially and densely welded tuff cores resulted in strains between 1 and 6 percent less than with staged tests. For an average core length of $80 \mathrm{~mm}$ and diameter of $60 \mathrm{~mm}$, the difference in volume reduction of core for 1 percent strain difference is about $2.3 \mathrm{ml}$. Considering the low degree of saturation and moisture contents of the partially and densely welded rock in Yucca Mountain, the quick test method appears to have the most potential to be used on nonwelded tuffs.

The second alternative test is the chips test. Sometimes it may be difficult to obtain intact core or the available core may be too large to fit into the cell. As a result, a pore-water extraction test for chips was developed. Several tests were run comparing porewater extraction success of tests on intact core and broken core. A Teflon wrap is put inside the cell to accommodate the chips, which are then placed in the cell and compacted into place. Very limited results may indicate that this test may be reasonable on nonwelded tuff chips with saturations of about 20 percent or greater. Additional test runs will be required for both of these methods to evaluate their potential for use on Yucca Mountain tuffs. 


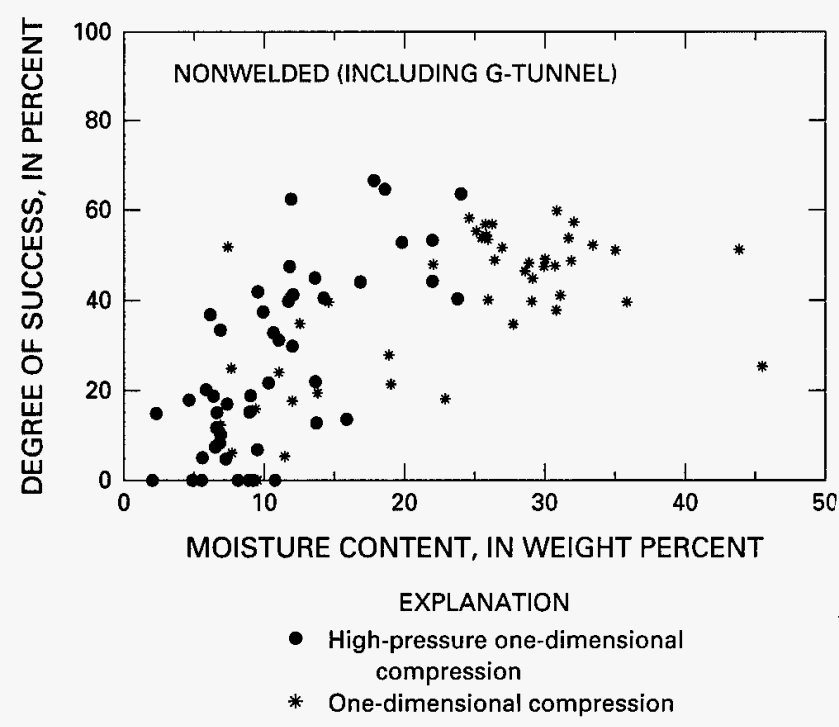

Figure 13. Relation between moisture content and degree of success for nonwelded tuff using one-dimensional and highpressure one-dimensional compression.

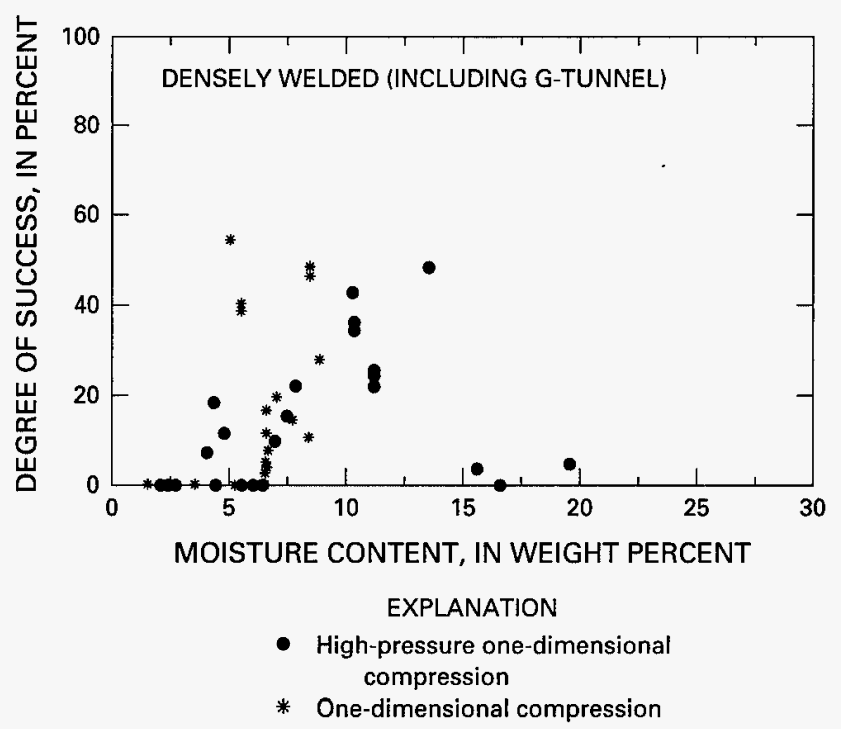

Figure 15. Relation between moisture content and degree of success for densely welded tuff using one-dimensional and high-pressure one-dimensional compression.

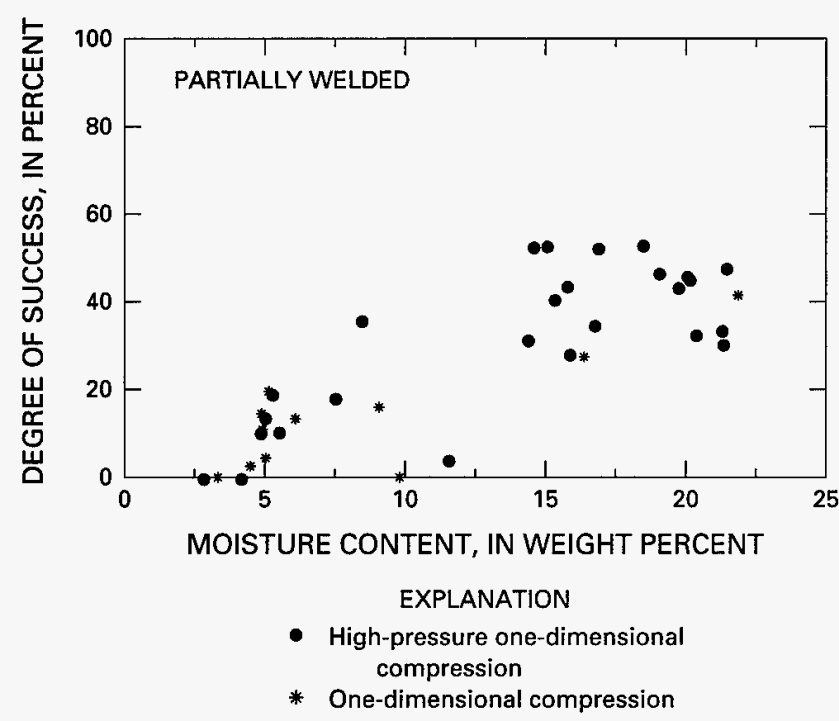

Figure 14. Relation between moisture content and degree of success for partially welded tuff using one-dimensional and high-pressure one-dimensional compression.

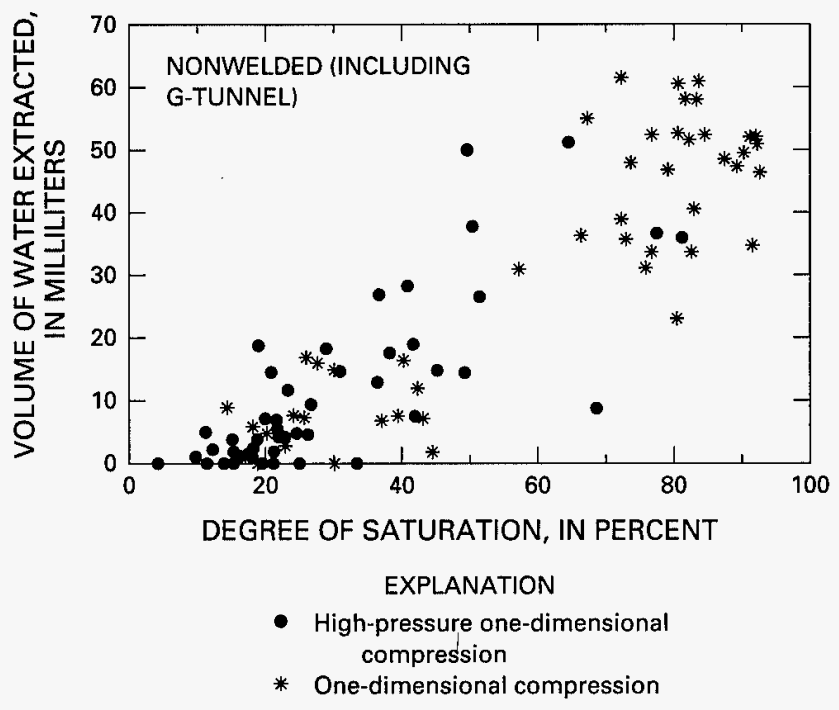

Figure 16. Relation between degree of saturation and volume of water extracted for nonwelded tuff using onedimensional and high-pressure one-dimensional compression. 


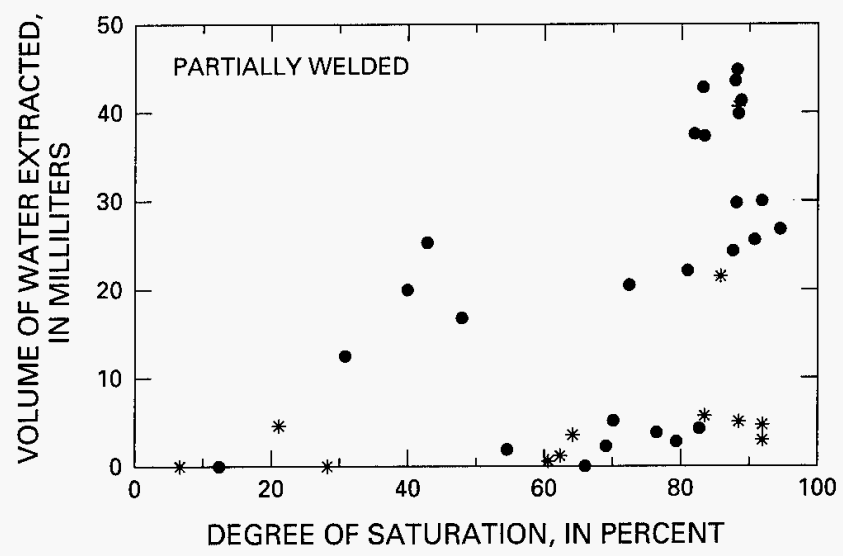

EXPLANATION

- High-pressure one-dimensional compression

* One-dimensional compression

Figure 17. Relation between degree of saturation and volume of water extracted for partially welded tuff using one-dimensional and high-pressure one-dimensional compression.

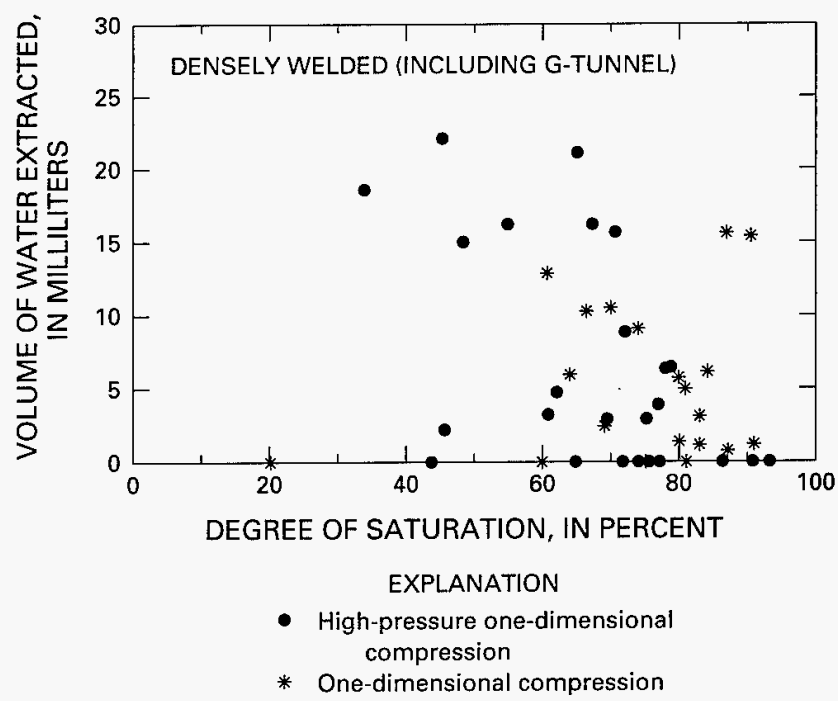

Figure 18. Relation between degree of saturation and volume of water extracted for densely welded tuff using onedimensional and high-pressure one-dimensional compression.

\section{Discussion of Compression Tests}

For the extraction of pore water from unsaturated tuff cores, both one-dimensional and highpressure one-dimensional compression have many advantages over the previously tested triaxial compression pore-water extraction method. These advantages are:

1. Larger applied axial stress. The one-dimensional compression cell can apply more than 2.5 times the axial stress to a core than previously used triaxial compression cells. The high-pressure one-dimensional compression cell can apply about 1.5 times the axial stress of the onedimensional compression cell. Larger axial stress causes more pore space to be eliminated during compression, which, in turn, results in increased water expulsion from nonwelded tuff cores. Large axial stresses are required to cause water expulsion from cores of nonwelded tuffs that have initial moisture contents less than about 11 percent and from any densely welded tuff cores.

2. Quantitative volumetric measurements. Because the core diameter is rigidly constrained during one-dimensional compression, relatively accurate volumetric measurements are possible. Lateral strain can occur during triaxial compression, and, therefore, accurate volume change measurements cannot be made. (Measurements of lateral strain - not possible with the triaxial compression equipment used in previous studies - would allow approximate volumetric measurements during compression.) Measurements of changes in core volume during compression are useful in predicting the approximate timing and volume of water expulsion.

3. Variable core length. Both the one-dimensional and high-pressure one-dimensional compression cells can accommodate a large range of core lengths. Standard triaxial compression cells require closely constrained core sizes.

4. Smaller system volume. About $1 \mathrm{ml}$ of water must be expelled into the collection system of either one-dimensional compression cell before water recovery is observed in the collection syringes. The triaxial compression cell used in this study required about $8 \mathrm{ml}$ to fill the collection system up to the syringes. (Modifications to the triaxial cell could reduce the required system volume.) A small system volume allows rapid recognition of water expulsion and minimizes the loss of water that adheres to the inside of the water drainage pathways.

5. Lower contamination risk. Because steel applies the confining force in the one-dimensional 
compression cell, there is no risk of contamination caused by leakage of the confining fluid as can occur in the triaxial compression cell.

The most important of all the listed advantages is the larger stress capacity of the two one-dimensional compression cells. Larger axial stresses produce larger volumes of expelled pore water in all tuff cores that have similar initial saturations (or moisture contents). Large axial stresses also enable extraction of pore water from nonwelded tuff cores that have small initial saturations (or moisture contents) and from densely welded tuff cores; neither of these two groups of tuff samples would produce water using triaxial compression.

The most appropriate method for pore-water extraction from Yucca Mountain tuffs can be selected based on two criteria: (1) the minimum initial moisture content required for successful pore-water extraction, and (2) the impact the method has on the original, in-situ pore-water chemistry. The two methods investigated in this study are considered below in relation to the first selection criterion. The second criterion, impact of method on original porewater chemistry, is discussed in the PORE-WATER CHEMISTRY section of this report.

The stratigraphic section above the water table at Yucca Mountain contains a much thicker sequence of partially to densely welded tuffs than nonwelded tuffs. Based on thicknesses reported in Montazer and Wilson (1984), the unsaturated zone at Yucca Mountain is about 90 percent partially to densely welded tuffs and only about 10 percent nonwelded tuffs. The most appropriate pore-water extraction method must, consequently, be based mainly on the ability of the method to remove pore water from partially and densely welded tuff cores. Both onedimensional and high-pressure one-dimensional compression can expel pore water from partially and densely welded tuff cores. In addition, both cells have smaller required initial saturations or moisture contents for pore-water extraction from nonwelded tuff cores than triaxial compression. Therefore, based on the mechanical capabilities of these pore-waterextraction methods, both one-dimensional compression cells are more appropriate for pore-water extraction from tuff cores than triaxial compression. Highpressure, one-dimensional compression has been the most successful of all methods used for pore-water extraction on partially and densely welded tuffs.
Either one-dimensional compression cell may be used with relative success on nonwelded tuffs.

\section{PORE-WATER CHEMISTRY}

\section{Chemical Analyses of Pore Water}

Suites of pore-water samples were collected from cores at increasing pressures to evaluate possible effects of one-dimensional compression on the chemistries of pore waters. It is desirable to have waters from the same core at several pressures to adequately make this evaluation. Since water content of all of the Yucca Mountain tuff cores is low, large numbers of sample suites from each core were not possible. However, suites of pore-water samples from cores representing five different geologic formations of tuff were collected and analyzed for $\mathrm{pH}$, specific conductance (SC), and common cations and anions. These analyses were performed on 75 water samples collected from 13 core samples. Samples analyzed included pore waters from nonwelded Calico Hills Formation, nonwelded Pah Canyon Tuff, nonwelded and densely welded Tiva Canyon Tuff, nonwelded Topopah Spring Tuff, and nonwelded bedded tuff of the Paintbrush Group. These samples allow analyses of waters extracted from core samples with variable lithology, mineralogy and moisture content.

Water analyses were performed using ionspecific electrodes, ion chromatography, atomic absorption, and colorimetric methods by a contract laboratory. A 3-ml water sample was required for a completed analysis.

A graphical comparison of pore-water composition and SC versus the applied stress is the most direct method of determining variations in pore-water chemistry as a function of stress of extraction. Table 2 lists one-dimensional compression test pressures at which water samples were collected and $\mathrm{SC}$ and $\mathrm{pH}$ for those samples. Specific conductance is plotted versus axial stress, and Piper trilinear diagrams representing the pore-water chemistries at different pressures for the samples listed in table 2 are presented in figures 19 through 44 . The SC plots are useful to illustrate general trends of ion concentrations as extraction pressure is increased. The trilinear diagrams are useful to illustrate any relative changes in major cation and anion composition as pore-water extraction pressures are increased and to classify the waters (Freeze and Cherry, 1979). 
Table 2. Chemical data for pore-water extraction using one-dimensional compression and high-pressure one-dimensional compression

[MPa, megapascals; $\mathrm{SC}$, specific conductance; $\mu \mathrm{S} / \mathrm{cm}$, microsiemens per centimeter]

\begin{tabular}{|c|c|c|c|}
\hline Sample name & $\begin{array}{c}\text { Axial stress } \\
\text { (MPa) }\end{array}$ & $\begin{array}{c}\mathbf{S C} \\
(\mu \mathbf{S} / \mathbf{c m})\end{array}$ & pH \\
\hline \multicolumn{4}{|c|}{ NWPC-1 } \\
\hline A & 175.95 & 920 & 6.5 \\
\hline 0 & 258.75 & 770 & 6.6 \\
\hline B & 258.75 & 860 & 6.5 \\
\hline 1 & 362.25 & 810 & 6.7 \\
\hline $\mathrm{C}$ & 414 & 820 & 6.7 \\
\hline 2 & 517.5 & 810 & 6.6 \\
\hline D & 672.75 & 840 & 6.5 \\
\hline 3 & 724.5 & 770 & 6.6 \\
\hline \multicolumn{4}{|c|}{ NWPC-2 } \\
\hline A & 329.8 & 1,230 & 6.9 \\
\hline 0 & 434.4 & 1,220 & 6.8 \\
\hline B & 459.5 & 1,100 & 6.7 \\
\hline $\mathrm{C}$ & 681 & 1,100 & 6.6 \\
\hline 1 & 682.4 & 1,040 & 6.8 \\
\hline \multicolumn{4}{|c|}{ NWTS } \\
\hline A & 92.5 & 570 & 6.6 \\
\hline B & 119.0 & 520 & 6.6 \\
\hline 0 & 130.4 & 570 & 6.8 \\
\hline $\mathrm{C}$ & 162.2 & 500 & 6.8 \\
\hline 1 & 227.7 & 510 & 6.6 \\
\hline D & 240.1 & 470 & 6.7 \\
\hline $\mathrm{E}$ & 336.7 & 430 & 6.6 \\
\hline 2 & 347.1 & 470 & 6.4 \\
\hline $\mathbf{F}$ & 497.5 & 360 & 6.7 \\
\hline 3 & 618.2 & 450 & 6.7 \\
\hline$G$ & 720.0 & 370 & 6.6 \\
\hline \multicolumn{4}{|c|}{ NWBT } \\
\hline 1 & 81.1 & 600 & 7.0 \\
\hline A & 74.5 & 610 & 7.1 \\
\hline B & 258.8 & 490 & 7.7 \\
\hline 2 & 465.8 & 440 & 7.5 \\
\hline \multicolumn{4}{|c|}{ NWCH-1 } \\
\hline A & 327.8 & 550 & 7.4 \\
\hline 0 & 434.7 & 620 & 7.8 \\
\hline B & 631.4 & 470 & 8.8 \\
\hline 1 & 710.7 & 460 & 8.8 \\
\hline \multicolumn{4}{|c|}{ NWCH-2 } \\
\hline A & 200.1 & 450 & 7.8 \\
\hline B & 241.5 & 490 & 7.9 \\
\hline C & 427.8 & 430 & 8.9 \\
\hline D & 579.6 & 420 & 9.0 \\
\hline $\mathrm{E}$ & 717.6 & 400 & 9.5 \\
\hline
\end{tabular}


Table 2. Chemical data for pore-water extraction using one-dimensional compression and high-pressure one-dimensional compression-Continued

[MPa, megapascals; SC, specific conductance; $\mu \mathrm{S} / \mathrm{cm}$, microsiemens per centimeter]

\begin{tabular}{|c|c|c|c|}
\hline Sample name & $\begin{array}{c}\text { Axial stress } \\
\text { (MPa) }\end{array}$ & $\begin{array}{c}\text { SC } \\
(\mu \mathrm{S} / \mathrm{cm})\end{array}$ & pH \\
\hline \multicolumn{4}{|c|}{ NWCH-3 } \\
\hline A & 241.5 & 580 & 7.9 \\
\hline 1 & 279.5 & 580 & 8.5 \\
\hline B & 483.0 & 580 & 9.2 \\
\hline 2 & 600.3 & 540 & 9.2 \\
\hline $\mathrm{C}$ & 748.7 & 550 & 9.5 \\
\hline \multicolumn{4}{|c|}{ DWTC-1 } \\
\hline A & 345 & 610 & 6.9 \\
\hline B & 355.4 & 730 & 7 \\
\hline C & 621 & 400 & 6.6 \\
\hline D & 621 & 560 & 6.8 \\
\hline \multicolumn{4}{|c|}{ DWTC-2 } \\
\hline A & 362.3 & 880 & 6.9 \\
\hline B & 517.5 & 750 & 6.8 \\
\hline D & 569.3 & 680 & 5.9 \\
\hline c & 724.5 & 670 & 6.7 \\
\hline \multicolumn{4}{|c|}{ NWTC-1 } \\
\hline A & 103 & 1,630 & 6.9 \\
\hline B & 103 & 1,410 & 6.7 \\
\hline $\mathrm{C}$ & 207 & 1,450 & 7.2 \\
\hline D & 414 & 1,080 & 7.3 \\
\hline E & 414 & 1,280 & 6.8 \\
\hline $\mathrm{F}$ & 690 & 1,160 & 6.7 \\
\hline G & 690 & 1,030 & 6.9 \\
\hline \multicolumn{4}{|c|}{ NWTC-2 } \\
\hline A & 103 & 770 & 6.4 \\
\hline B & 103 & 750 & 6.0 \\
\hline $\mathrm{C}$ & 172 & 700 & 6.2 \\
\hline D & 241 & 680 & 6.7 \\
\hline E & 310.5 & 650 & 6.4 \\
\hline$F$ & 483 & 530 & 6.0 \\
\hline G & 483 & 680 & 6.3 \\
\hline \multicolumn{4}{|c|}{ NWTC-3 } \\
\hline A & 11.5 & 750 & 6.1 \\
\hline B & 23 & 690 & 6.5 \\
\hline C & 34.5 & 710 & 6.5 \\
\hline D & 46 & 730 & 6.4 \\
\hline $\mathrm{E}$ & 57.5 & 660 & 6.6 \\
\hline $\mathrm{F}$ & 69 & 690 & 6.5 \\
\hline \multicolumn{4}{|c|}{ NWTC-4 } \\
\hline A & 34.5 & 780 & 6.3 \\
\hline B & 34.5 & 760 & 6.3 \\
\hline C & 34.5 & 710 & 6.3 \\
\hline D & 103 & 670 & 6.3 \\
\hline $\mathrm{E}$ & 207 & 550 & 5.8 \\
\hline
\end{tabular}


NWPC-1

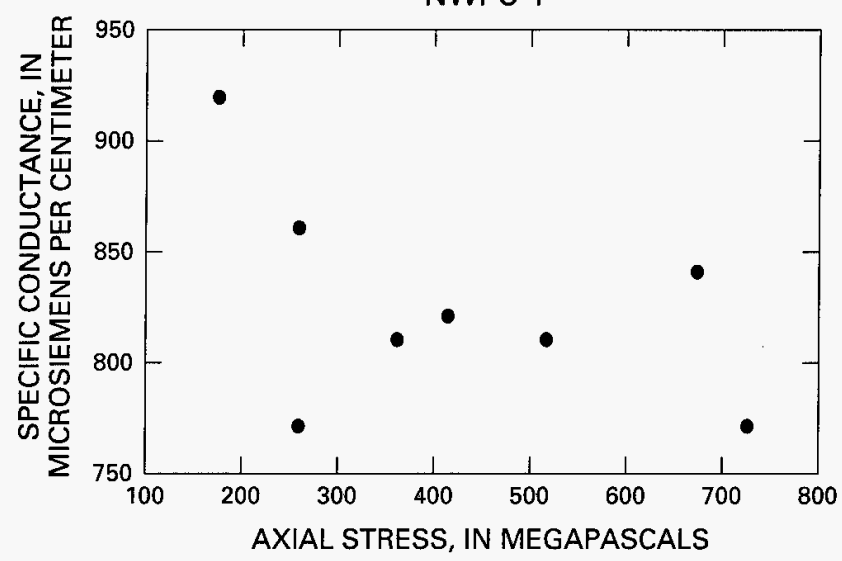

Figure 19. Relation of specific conductance to applied axial stress for pore-water sample NWPC-1.

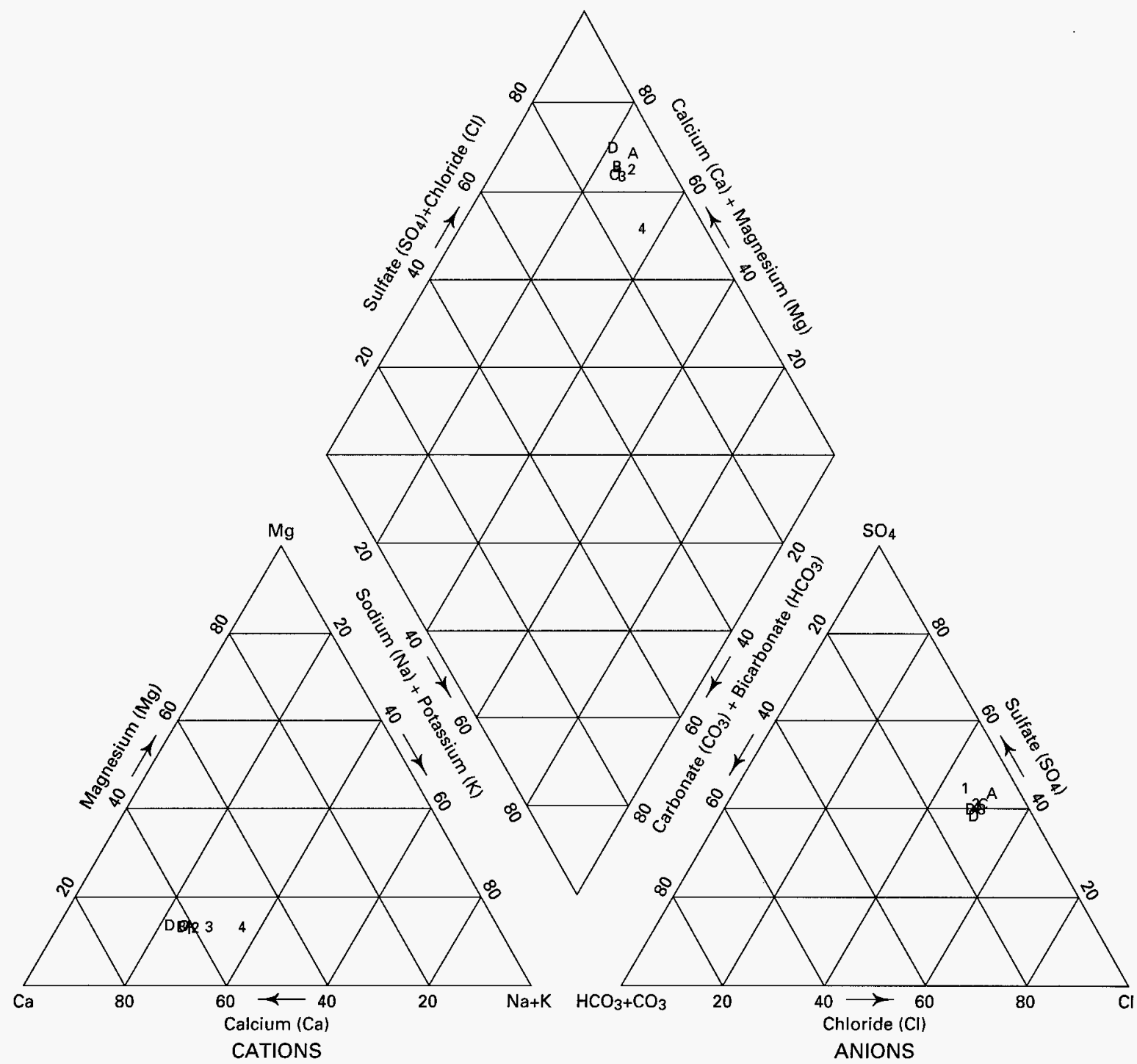

PERCENT MILLIEQUIVALENTS PER LITER

NWPC-1

Figure 20. Relative concentrations of cations and anions in pore-water sample NWPC-1 in percent milliequivalents per.liter.

18 The One-Dimensional Compression Method for Extraction of Pore Water from Unsaturated Tuff and Effects on Pore-Water Chemistry 

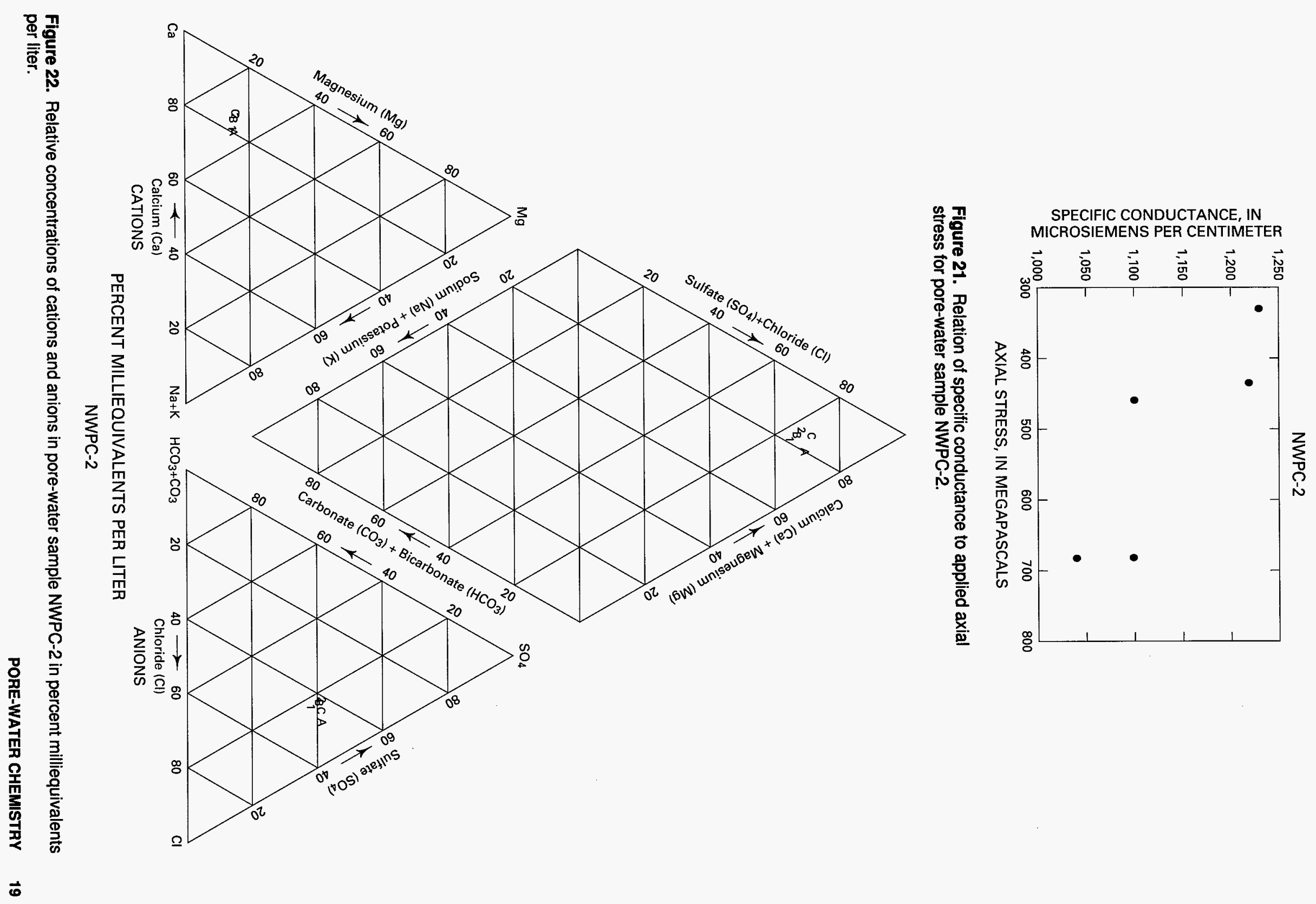


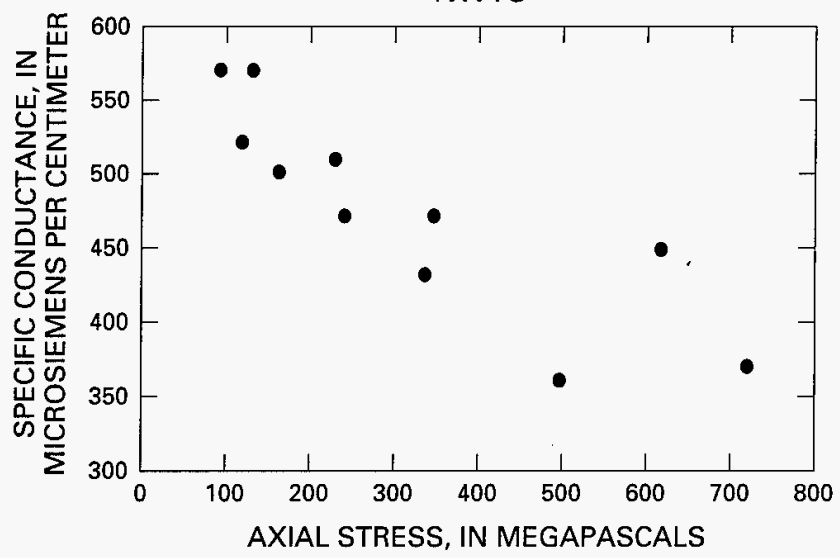

Figure 23. Relation of specific conductance to applied axial stress for pore-water sample NWTS.

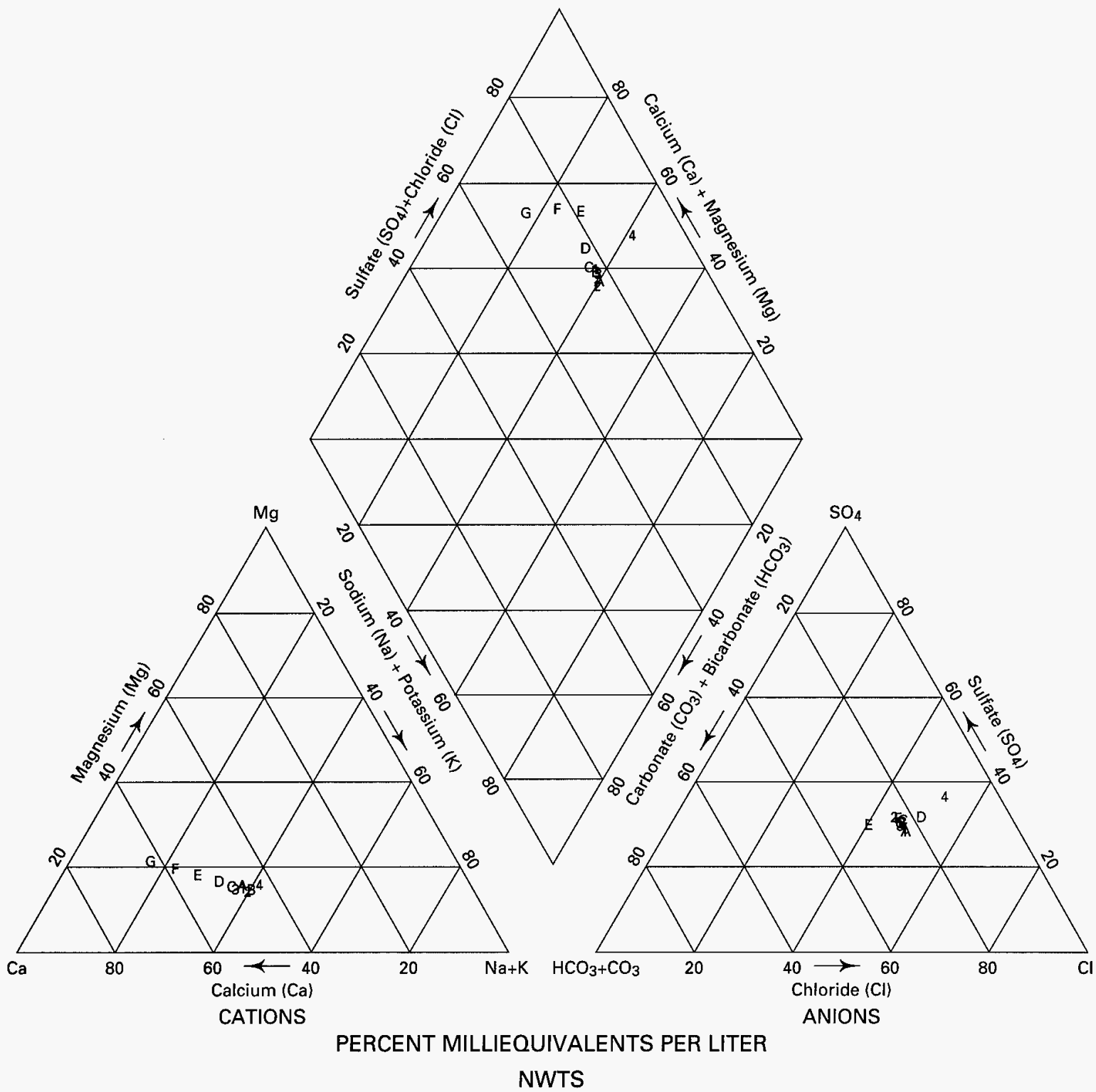

Figure 24. Relative concentrations of cations and anions in pore-water sample NWTS in percent milliequivalents per liter. 

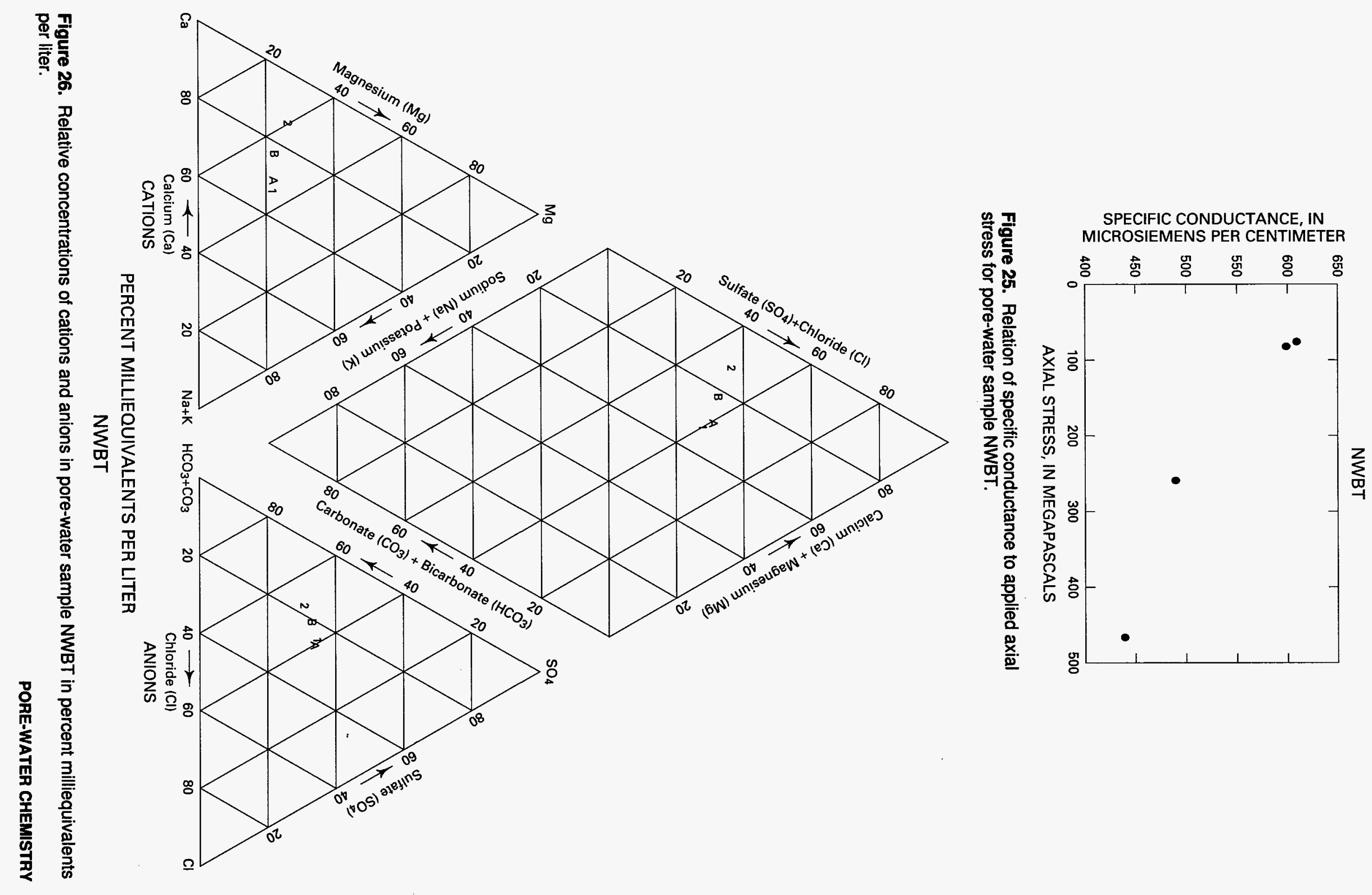


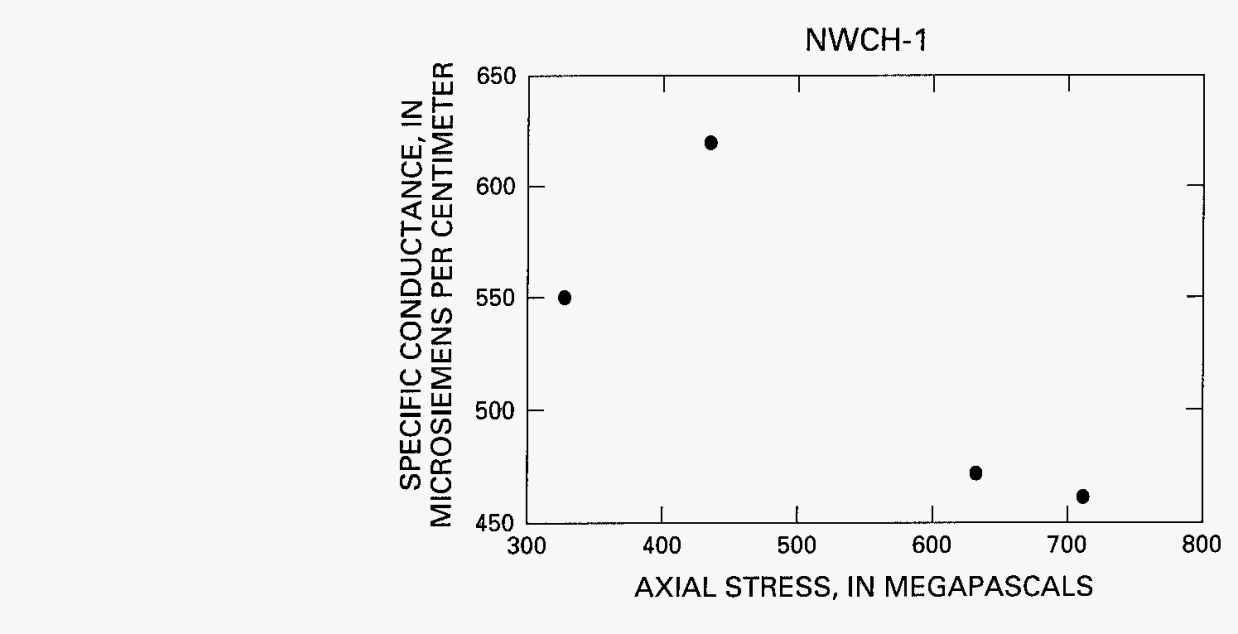

Figure 27. Relation of specific conductance to applied axial stress for pore-water sample NWCH-1.

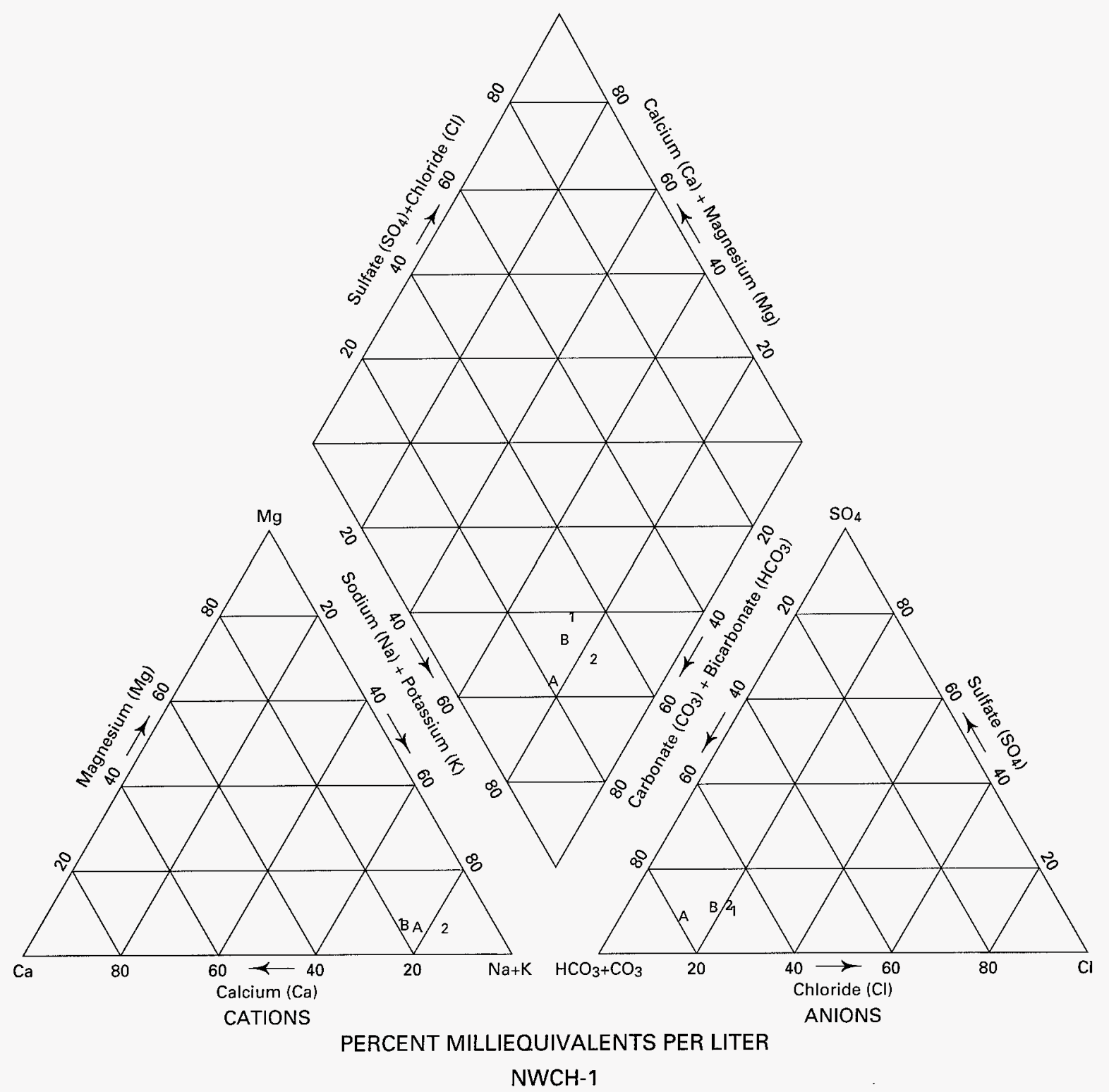

Figure 28. Relative concentrations of cations and anions in pore-water sample $\mathrm{NWCH}-1$ in percent milliequivalents per liter.

22 The One-Dimensional Compression Method for Extraction of Pore Water from Unsaturated Tuff and Effects on Pore-Water Chemistry 
$\mathrm{NWCH}-2$

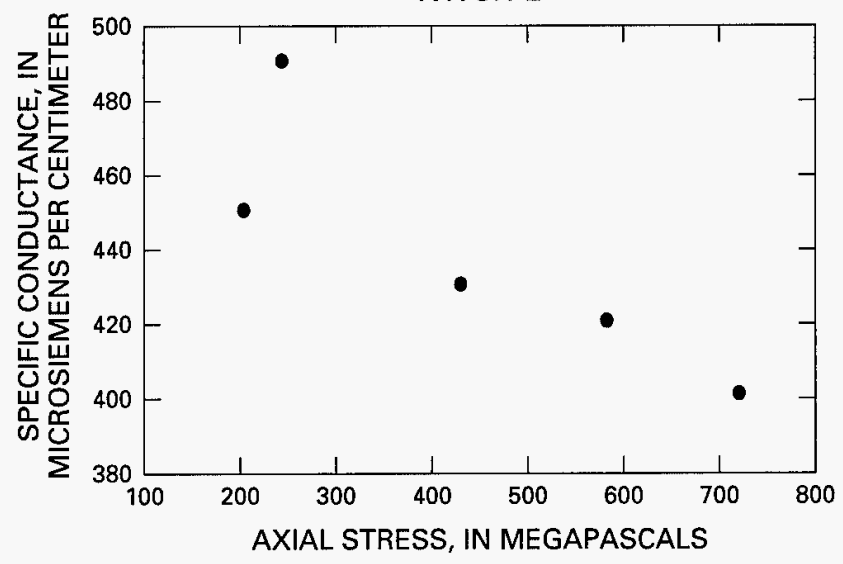

Figure 29. Relation of specific conductance to applied axial stress for pore-water sample NWCH-2.

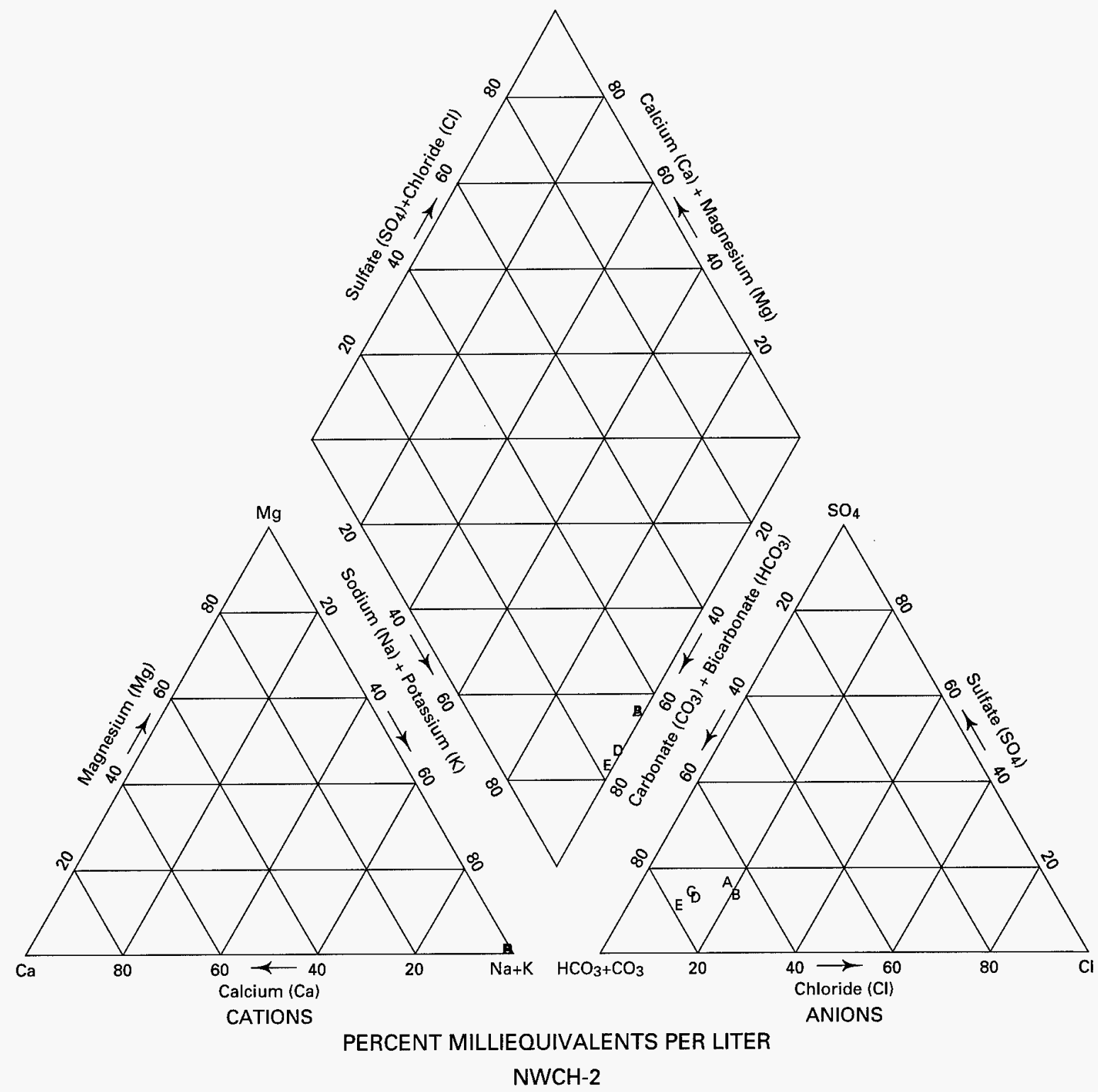

Figure 30. Relative concentrations of cations and anions in pore-water sample NWCH-2 in percent milliequivalents per liter. 
$\mathrm{NWCH}-3$

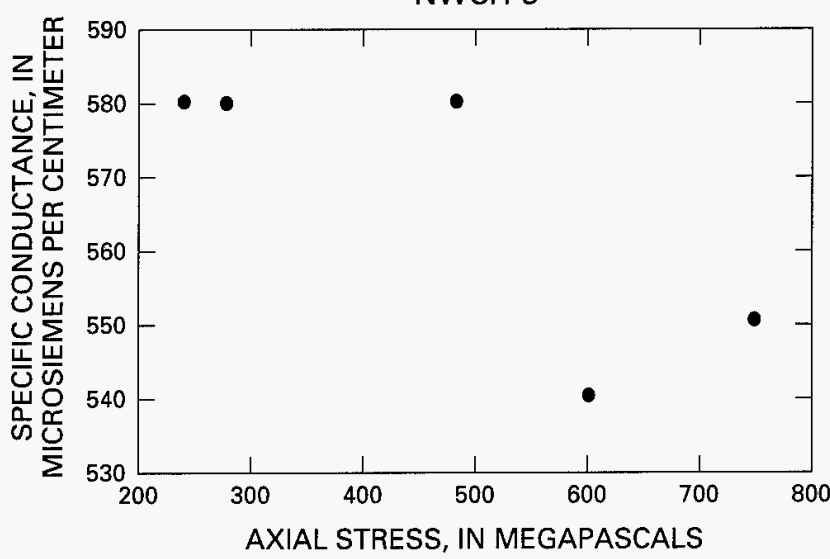

Figure 31. Relation of specific conductance to applied axial stress for pore-water sample NWCH-3.

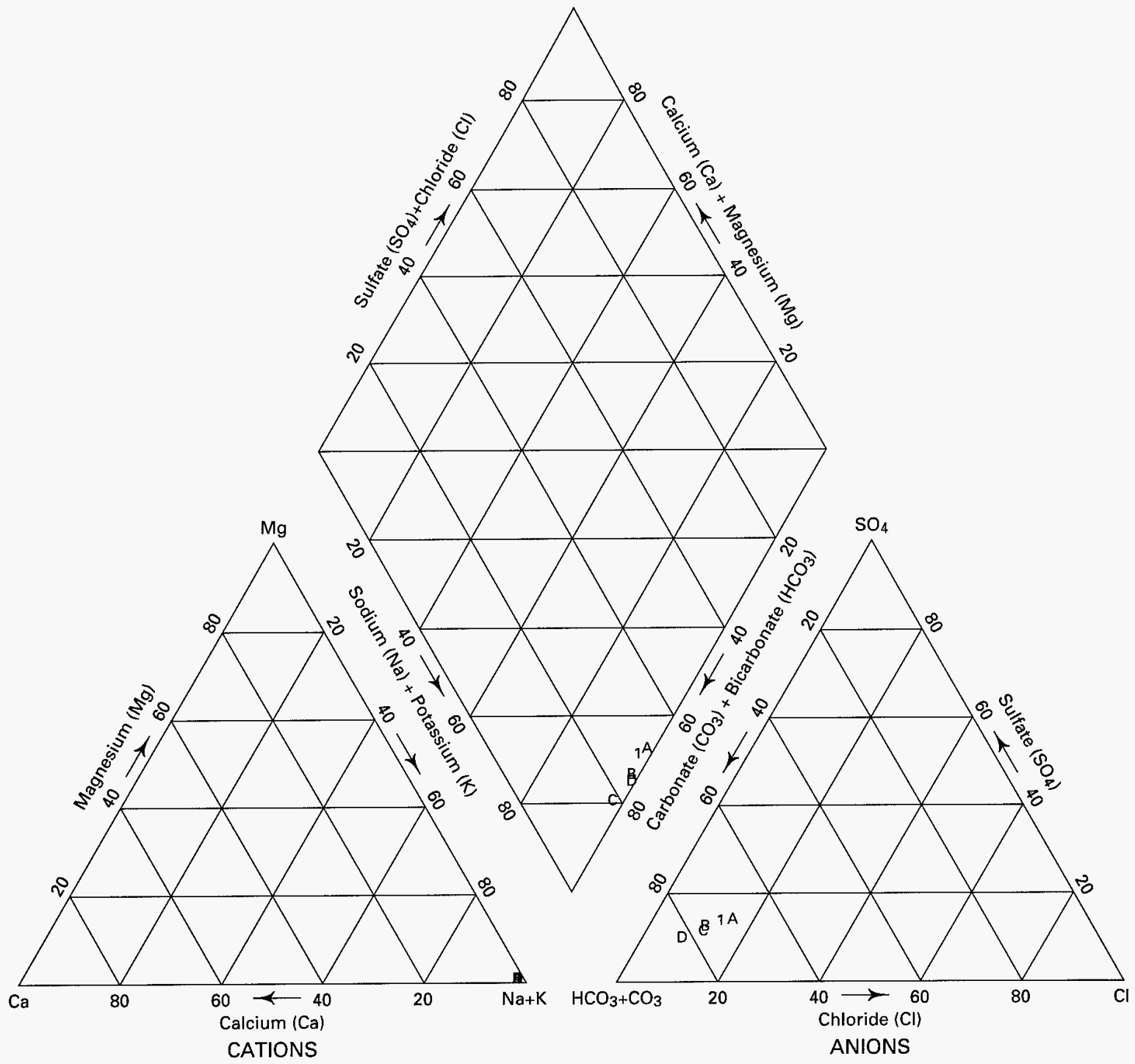

PERCENT MILLIEQUIVALENTS PER LITER

NWCH-3

Figure 32. Relative concentrations of cations and anions in pore-water sample NWCH-3 in percent milliequivalents per liter. 


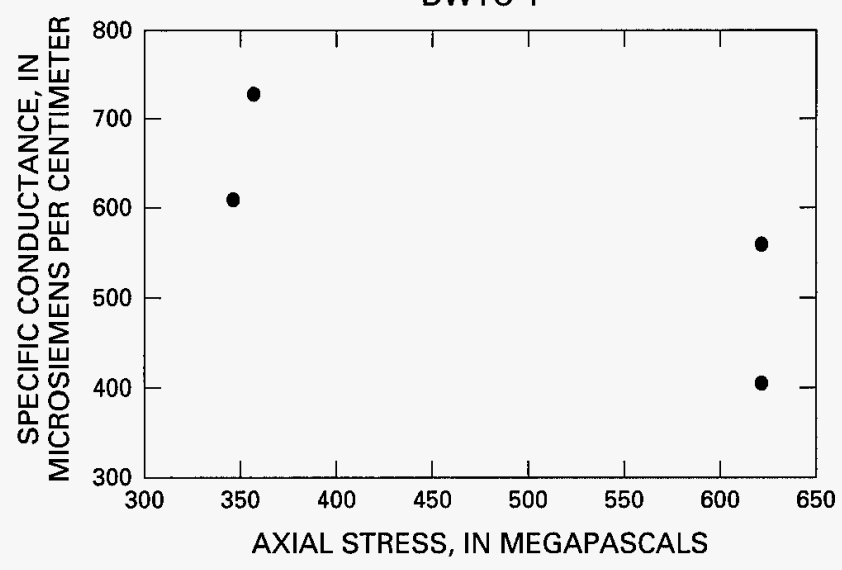

Figure 33. Relation of specific conductance to applied axial stress for pore-water sample DWTC-1.

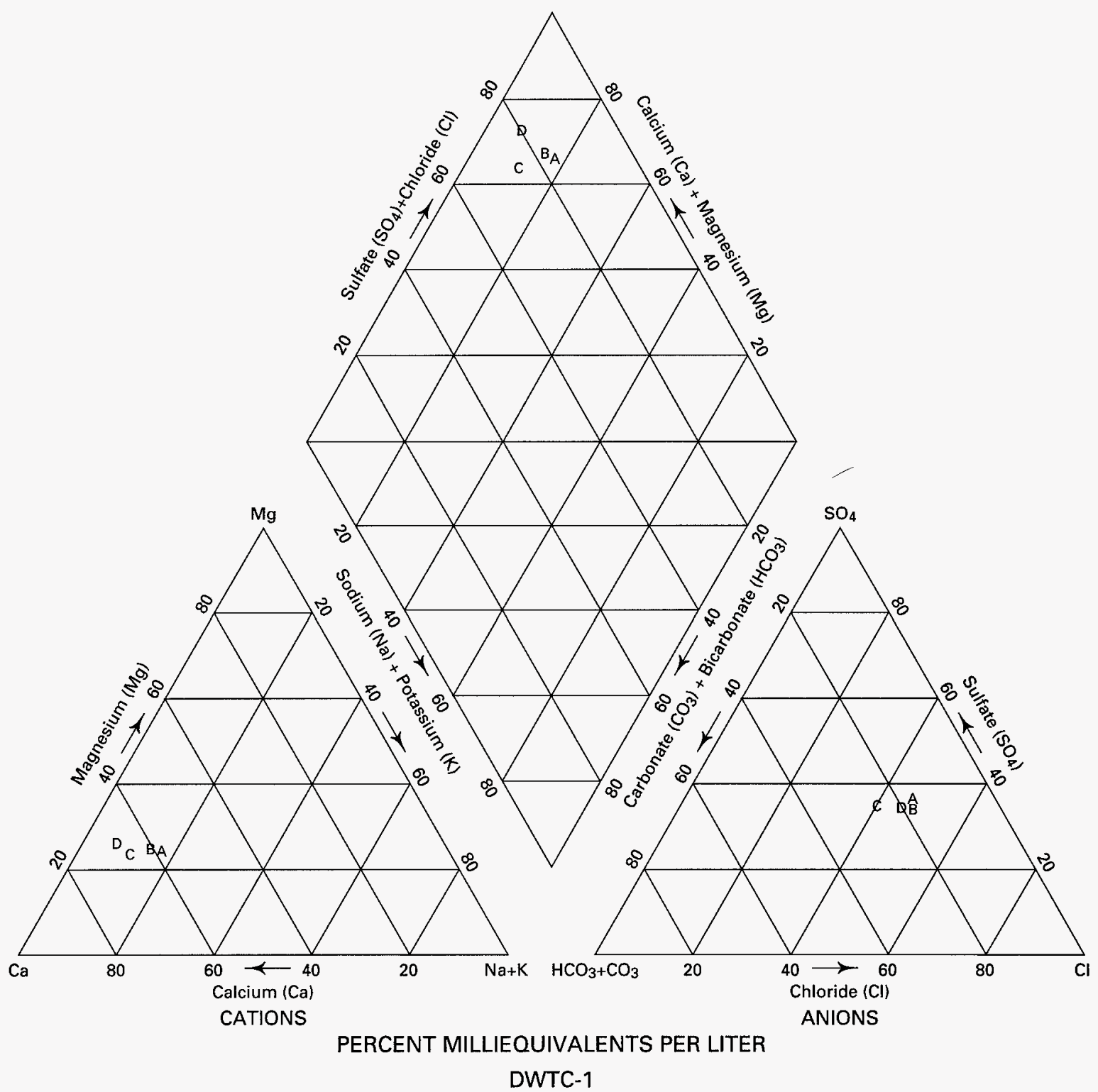

Figure 34. Relative concentrations of cations and anions in pore-water sample DWTC-1 in percent milliequivalents per liter. 

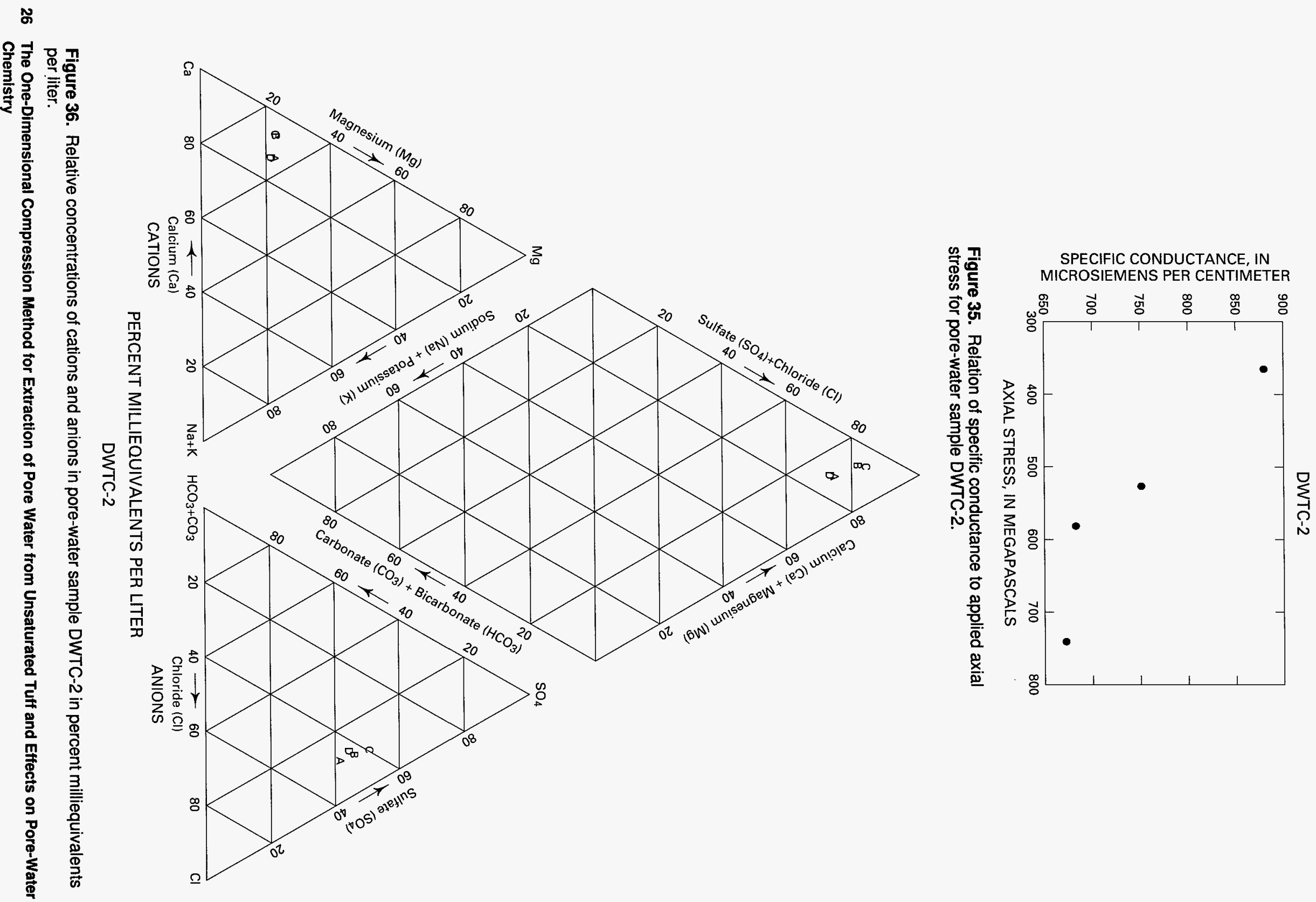

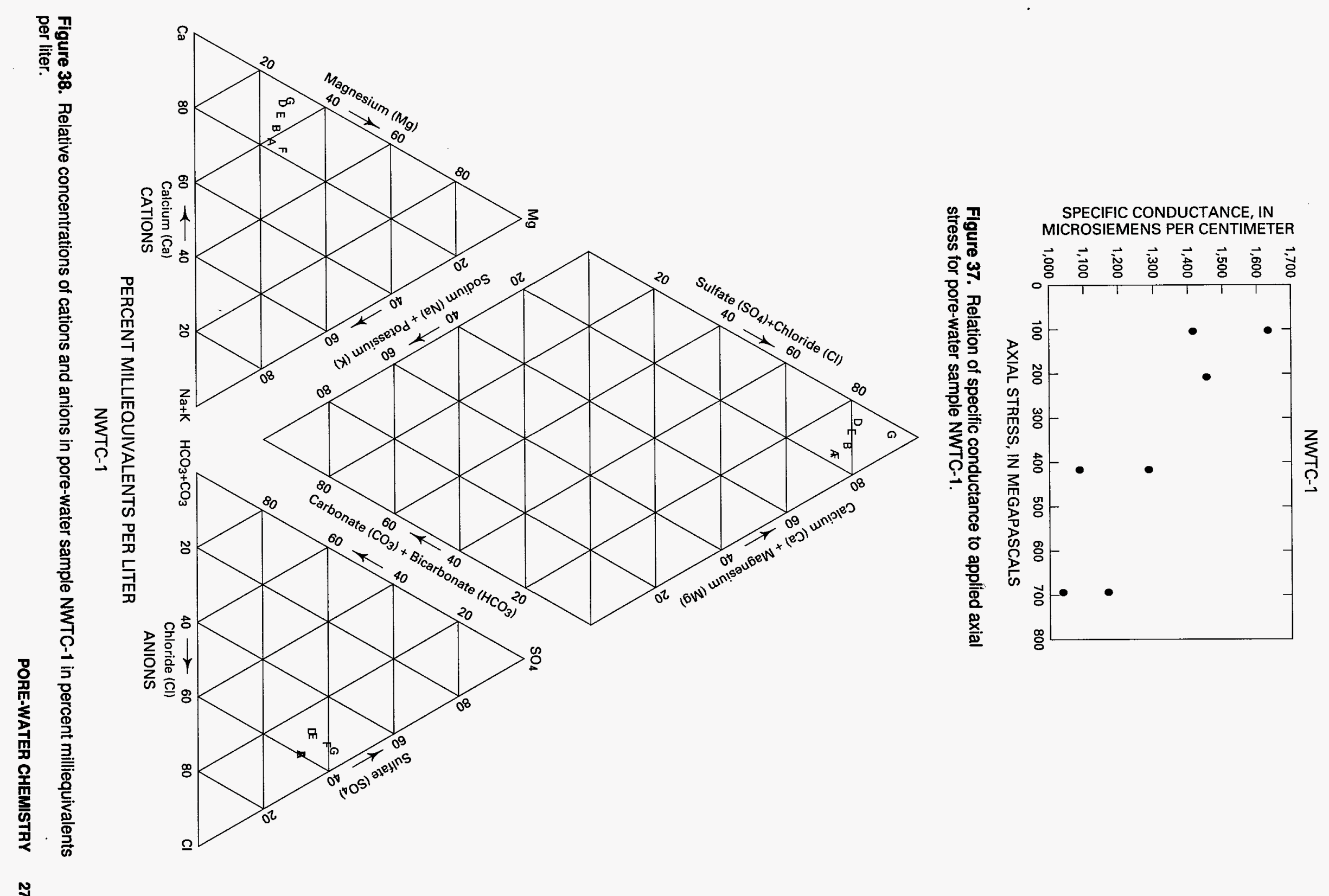
NWTC-2

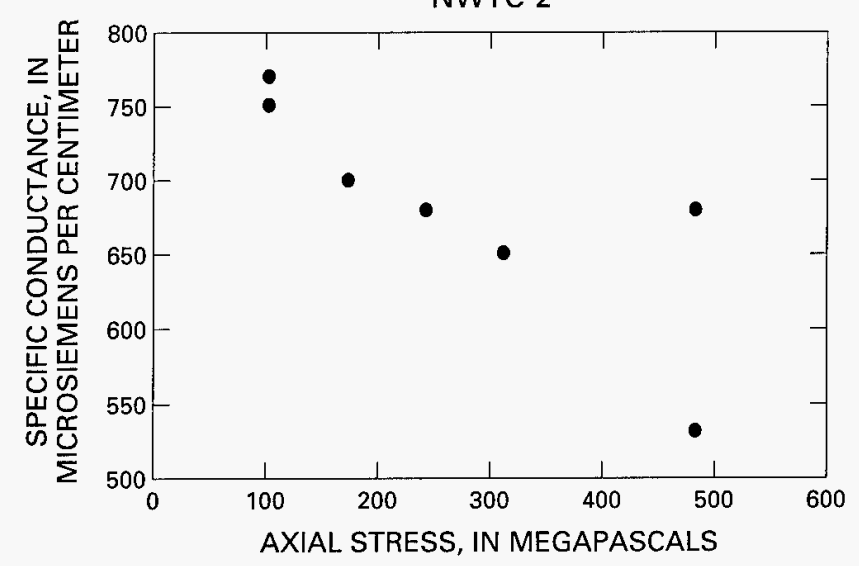

Figure 39. Relation of specific conductance to applied axial stress for pore-water sample NWTC-2.

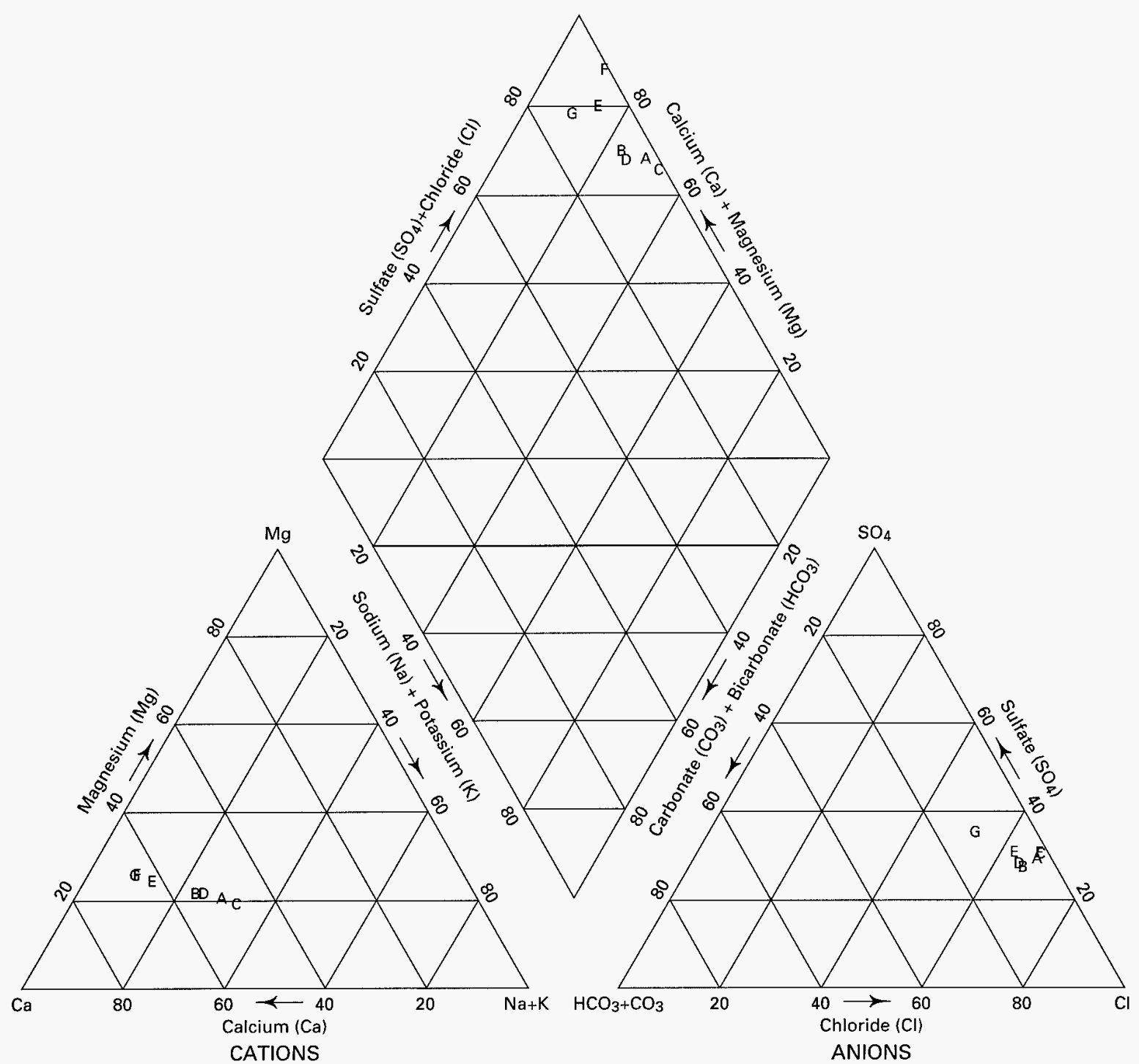

PERCENT MILLIEQUIVALENTS PER LITER

NWTC-2

Figure 40. Relative concentrations of cations and anions in pore-water sample NWTC-2 in percent milliequivalents per liter.

The One-Dimensional Compression Method for Extraction of Pore Water from Unsaturated Tuff and Effects on Pore-Water Chemistry 


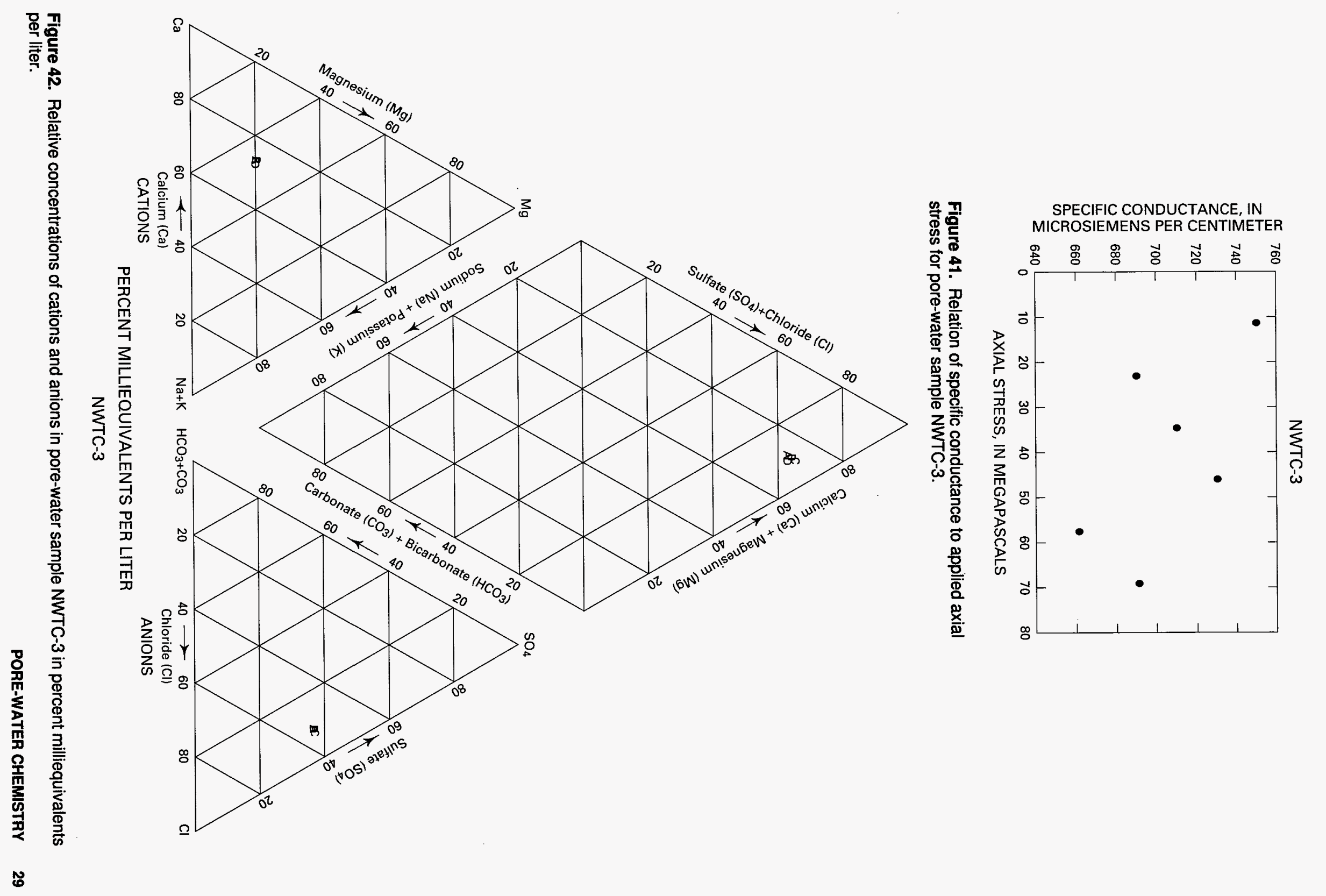


NWTC-4

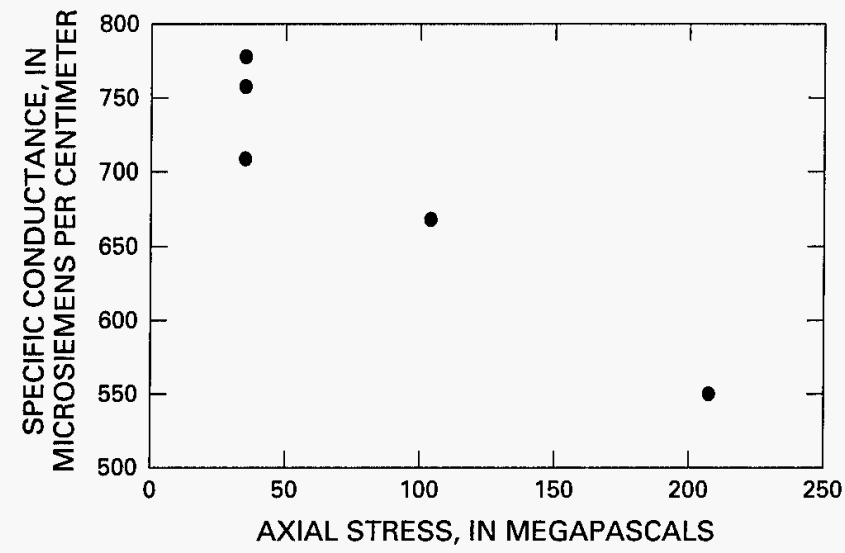

Figure 43. Relation of specific conductance to applied axial stress for pore-water sample NWTC-4.

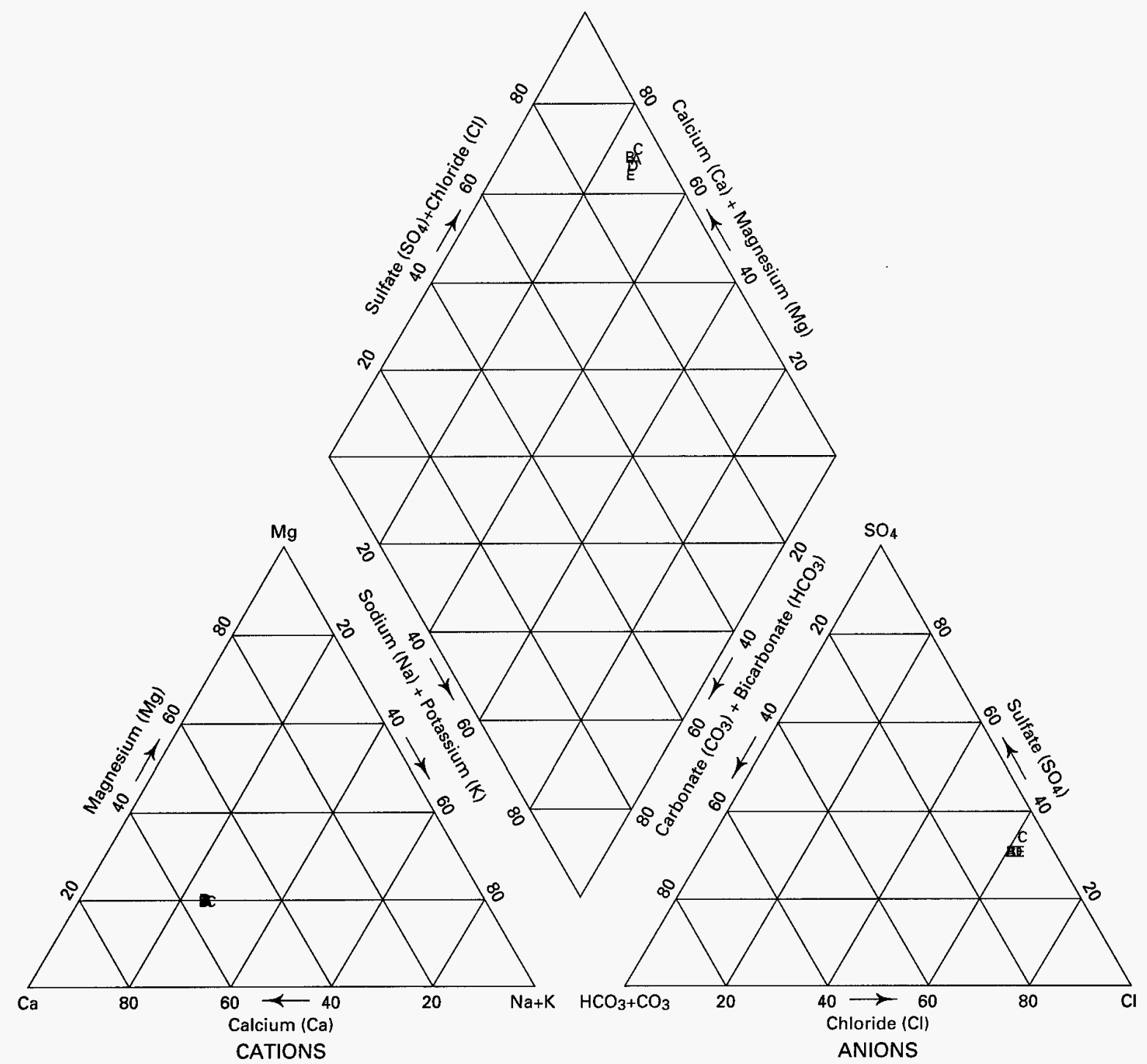

PERCENT MILLIEQUIVALENTS PER LITER

NWTC-4

Figure 44. Relative concentrations of cations and anions in pore-water sample NWTC-4 in percent milliequivalents per. liter.

The One-Dimensional Compression Method for Extraction of Pore Water from Unsaturated Tuff and Effects on Pore-Water Chemistry 
Suites of pore water were extracted from two core samples of nonwelded cores of Pah Canyon Tuff. Eight water samples were collected from seven pressure levels over a range of 176 to $725 \mathrm{MPa}$ for core sample NWPC-1. Specific conductance decreased by about 16 percent (fig. 19), and $\mathrm{pH}$ fluctuated between 6.5 and 6.7 as extraction pressure increased. The pore water is a borderline calcium chloride type (fig. 20). The relative amounts of calcium versus sodium/potassium fluctuated slightly as pressure increased. Five water samples were collected from four pressure levels over a range of 330 to $682 \mathrm{MPa}$ for core sample NWPC-2. Specific conductance decreased by about 15.5 percent (fig. 21 ), and $\mathrm{pH}$ fluctuated between 6.6 and 6.9 as extraction pressure increased. The pore-water samples were classified as a calcium type (fig. 22). The ratio of major cations and anions show little change as pressure of extraction increased. Tests on both cores produced very similar pore-water chemistries.

Twelve samples of pore water were extracted from one core sample of nonwelded Topopah Spring Tuff (sample NWTS). These were collected at 11 pressure levels over a range of 92.5 to $720 \mathrm{MPa}$. Specific conductance fluctuated, but generally decreased by approximately 35 percent (fig. 23 ), and $\mathrm{pH}$ fluctuated between 6.4 and 6.8 as extraction pressure was increased. At low pressures the pore waters classify as no dominant types, and at high pressures the waters are calcium types. Figure 24 shows that waters from the top drainage plate plotted closely with the first water collected at the bottom of the sample; however, the bottom sample showed a relative change in the calcium and sodium ratio as pressure increased.

A suite of four pore-water samples were extracted from a nonwelded core sample of the bedded tuff unit (sample NWBT) at four pressure levels (between 81 and $466 \mathrm{MPa}$ ). Specific conductance decreased by about 27 percent (fig. 25), and $\mathrm{pH}$ fluctuated, but increased overall from 7.0 to 7.7 as pressure increased. The extracted pore water ranged from a bicarbonate type at low pressure to a calcium bicarbonate type at high pressure. At the highest extraction pressure, the ratio of calcium to sodium increased over that of the lowest extraction pressure (fig. 26).

Suites of pore-water samples were extracted and analyzed from three tuff cores from the Calico Hills Formation. Four water samples were collected at four pressure levels between 327 and $711 \mathrm{MPa}$ from sample NWCH-1. Specific conductance fluctuated (increased at low pressures and decreased at higher pressures), but overall showed a decrease of approximately 26 percent as pressure increased (fig. 27); $\mathrm{pH}$ increased with pressure. The resulting pore water is a sodium bicarbonate type. Fluctuations in cation ratios and anion ratios are less than about 10 percent (fig. 28). Five water samples were collected at five pressure levels between 200 and $718 \mathrm{MPa}$ from sample NWCH-2. Specific conductance increased slightly between 200 and $242 \mathrm{MPa}$ and then decreased by approximately 18 percent as pressure increased to $718 \mathrm{MPa}$ (fig. 29). All samples are sodium bicarbonate-type waters. Figure 30 shows that the bicarbonate versus chloride content increased less than 15 percent as pressure increased, but overall water chemistry changed little with increasing pressure. Five water samples were collected at five pressure levels between 242 and $749 \mathrm{MPa}$ from sample NWCH-3. Specific conductance remained constant up to a pressure of $483 \mathrm{MPa}$ and declined about seven percent at higher pressures (fig. 31); the $\mathrm{pH}$ increased from 7.9 to 9.5. All samples are a sodium bicarbonate type (fig. 32). Bicarbonate increased about 15 percent at high pressures. Pore-water extraction tests on all three nonwelded tuff samples from the Calico Hills Formation produced similar pore waters, and progressively increased extraction pressure caused minimal variation in water chemistry.

Suites of pore-water samples were extracted and analyzed from two densely welded cores of Tiva Canyon Tuff. Four water samples at three pressure levels between 345 and $621 \mathrm{MPa}$ were collected from core sample DWTC-1. Specific conductance fluctuated, varying as much as $45 \%$ between the highest and lowest values (fig. 33), and $\mathrm{pH}$ fluctuated between 6.6 and 7 with increasing pressure. Water samples were classified as calcium types. Fluctuations of anion ratios or cation ratios were 10 percent or less. Figure 34 shows little change in water chemistry between the highest and lowest extraction pressures. Four water samples at four pressure levels between 362 and $725 \mathrm{MPa}$ were collected from core sample DWTC-2. Specific conductance decreased about 24 percent (fig. 35), and $\mathrm{pH}$ varied from 6.9 to 5.9. All samples are calcium types (fig. 36). Similar to sample DWTC-1, fluctuations of anion ratios or cation ratios were 10 percent or less. Pore-water extraction tests on both densely welded Tiva Canyon cores produced waters with similar chemistries, and progressively increasing extraction pressures caused only small variations in water chemistry. 
Four suites of pore-water samples were extracted from four nonwelded cores of Tiva Canyon Tuff. Seven water samples were collected at four pressure levels between 103 and $690 \mathrm{MPa}$ from sample NWTC-1. As pressure was increased, SC for the extracted pore waters decreased by 37 percent (fig. 37), and $\mathrm{pH}$ fluctuated from 6.7 to 7.3 . Pore waters are a calcium chloride type. Figure 38 shows fluctuations in cation ratios ranging up to about 18 percent and fluctuations in anion ratios ranging up to about 10 percent as the pressure increased. Although the calcium ratio fluctuated, in general, it appears to increase with progressively higher extraction pressures. Seven water samples were collected at five pressure levels between 103 and $483 \mathrm{MPa}$ from sample NWTC-2. Specific conductance varied by about 31 percent (fig. 39), and $\mathrm{pH}$ fluctuated between 6 and 6.7 as water was extracted at progressively higher pressures. Similar to samples collected from NWTC-1, the waters are a calcium chloride type, and the Piper trilinear plots (figs. 38 and 40) show similar trends in calcium versus sodium content. Six water samples were collected at low pressures (between 11.5 and $69 \mathrm{MPa}$ ) for core sample NWTC-3. Specific conductance fiuctuated but decreased overall (fig. 41), and $\mathrm{pH}$ fluctuated but increased overall from 6.1 to 6.6. All pore-water samples are a calcium chloride type. The Piper trilinear plot (fig. 42) shows a very tight grouping of pore-water chemistry, which indicates little change in relative chemical composition of waters as pressure increased. Five water samples were collected at low to moderate pressures (between 34.5 and $207 \mathrm{MPa}$ ) for core sample NWTC-4. Specific conductance decreased by about 30 percent (fig. 43 ), and $\mathrm{pH}$ decreased from 6.3 to 5.8 as pressure increased. All extracted pore waters are a calcium chloride type. The Piper trilinear plot (fig. 44) is very similar to that of sample NWTC-3 (fig. 42), which indicates very little change in water chemistry.

\section{Discussion of Pore-Water Chemistry}

In general, the extraction of sequential porewater samples at progressively higher pressures from a single core shows that there is a decrease in the ion concentration. In most tests this was manifested in an increase in calcium and a decrease in sodium, resulting in a decrease in SC. Similar results were obtained by Entwisle and Reeder (1993) during tests of a squeezing device for mudrocks and clays. In all but a few tests, these changes were small. Water was extracted from samples NWTC-3 and -4 at pressures less than 69 and $207 \mathrm{MPa}$ respectively, which resulted in essentially no changes in relative chemical concentrations from lowest to highest extraction pressures. Chemical changes did occur in most tests; however, shifts in the trilinear plots show that these were small with a few exceptions. Analyses of samples NWTC-3 and -4 indicate that pore waters with the least chemical alteration are obtained at the lowest extraction pressures, or the first water samples expelled. Extraction pressures below $200 \mathrm{MPa}$ appear not to affect pore-water chemistry. Progressively higher extraction pressures may cause small changes in the calcium/sodium ratios.

\section{Potential Mechanisms for Changes in Pore-Water Chemistry}

Peters and others (1992) suggested three most probable mechanisms responsible for changes in ion concentrations in pore water that occur as a function of increasing pressure during compression of tuff core samples. These are:

1. Dilution of pore water may occur by compression of clays and zeolites and release of ion-deficient, previously-bound water. Nonwelded tuffs from the tested units often contain significant amounts of clay minerals and zeolites. As shown in table 2, ion concentrations tend to decrease as pressure was increased in all the samples tested, which is consistent with this mechanism.

2. The interaction of pore water with carbon dioxide gas contained in unfilled pore space would form a weak carbonic acid solution that could cause pH or alkalinity changes and dissolve minerals. Table 2 shows that $\mathrm{pH}$ tended to change as pressure of extraction was increased, which may partially support this mechanism.

3. The compressed clay and zeolite minerals may act as a semipermeable membrane causing a decrease of ion concentration and a change in the relative proportions of sodium. Most of the samples analyzed show at least a small reduction in the amount of sodium versus calcium as 
extraction pressure is increased, which appears to support this mechanism.

\section{SUMMARY AND CONCLUSIONS}

Two generations of one-dimensional compression cells were designed and fabricated to extract samples of unaltered pore water from unsaturated tuff cores. The equipment was tested on tuff cores from Yucca Mountain, Nevada, and the NTS, and a repeatable technique for extracting pore water was developed. Testing included 86 one-dimensional compression tests and 109 high-pressure onedimensional compression tests.

For one-dimensional compression, the minimum initial degree of saturation for successful extraction of pore water was about 14 percent for nonwelded tuff, and about 61 percent for densely welded tuff. High-preśsure, one-dimensional compression tests showed that the minimum initial saturation for pore-water extraction was about 7.5 percent for nonwelded tuff, about 31 percent for partially welded tuff, and about 34 percent for densely welded tuff.

In general, cores that have a larger initial degree of saturation (or moisture content) produce more water when compressed than cores that have a smaller initial saturation (or moisture content) assuming rock strength is similar. Also, the high-pressure onedimensional compression system usually results in larger extraction success (larger volumes of water extracted) than the one-dimensional compression system, especially for partially and densely welded tuffs.

For the extraction of pore water from unsaturated tuff cores, both one-dimensional and highpressure one-dimensional compression have many advantages over previously tested triaxial compression methods. The one-dimensional compression cells apply much higher axial stresses and cause more compaction of rock samples, allow volumetric measurements to aid the testing procedure, allow variable core lengths to be used, lose less water in the system, and lower the risk of contamination of the pore-water samples over the triaxial compression systems.

The stratigraphic section above the water table at Yucca Mountain contains about 90 percent partially to densely welded tuffs and only about 10 percent nonwelded tuffs. Both one-dimensional and highpressure one-dimensional compression can expel pore water from partially welded and densely welded tuff cores. In addition, both cells have smaller required initial saturations or moisture contents for pore-water extraction from nonwelded tuff cores than triaxial compression. Based on the mechanical capabilities of these extraction methods, both one-dimensional compression cells are more appropriate for pore-water extraction from tuff cores than triaxial compression. High-pressure one-dimensional compression has been most successful of all methods on partially and densely welded tuffs. Either one-dimensional compression system may be used successfully on nonwelded tuffs.

Geochemical analyses have shown that, in general, there is a decrease in ion concentration in extracted pore waters with increasing extraction pressures. Major cation and anion ratios may change as pressure increases; however, these changes are small in most cases. The least chemically altered pore water is the first to be extracted at the lowest possible extraction pressures.

The one-dimensional compression test is a reliable method for extraction of pore water from low moisture content tuff units at Yucca Mountain. It is the only method known to the authors that can be used for extraction of pore water for geochemical analyses of low permeability, high strength, and low moisturecontent materials.

\section{SELECTED REFERENCES}

American Society for Testing and Materials, 1988a, Laboratory determination of water (moisture) content of soil, rock, and soil-aggregate mixtures: Annual Book of ASTM Standards, v. 4.08, D 2216-80, p. 357-360.

- 1988b, Triaxial compressive strength of undrained rock core specimens without pore pressure measurements: Annual Book of ASTM Standards, v. 4.08, D 2664-86, p. 431-436.

Barneyback, R.S., Jr., and Diamond, S., 1981, Expression and analysis of pore fluids from hardened cement pastes and mortars: Cement and Concrete Research, v. 11, p. 279-285.

Byers, F.M., Jr., Carr, W.J., Orkild, P.P., Quinlivan, W.D., and Sargent, K.A., 1976, Volcanic suites and related cauldrons of Timber Mountain-Oasis Valley Caldera Complex, southern Nevada: U.S. Geological Survey Professional Paper 919, $70 \mathrm{p}$. 
Dropek, R.K., and Levinson, A., 1975, Water extraction from Nevada Test Site tuffs in Progress Report II: Terra Tek Report TR 75-52, p. 343-359.

Entwisle, D.C., and Reeder, S., 1993, New apparatus for pore fluid extraction from mudrocks for geochemical analysis in Manning, D.A.C., Hall, P.L., and Hughes, C.R., eds., Geochemistry of clay-pore fluid interactions: London, Chapman and Hall, p. 365-388.

Freeze, R.A., and Cherry, J.A., 1979, Groundwater: Englewood Cliffs, N.J., Prentice-Hall, Inc., p. 252.

Gibbons, A.B., Hinrichs, E.N., Hansen, W.R., and Lemke, R.W., 1963, Geology of the Rainier Mesa Quadrangle, Nye County, Nevada: U.S. Geological Survey Geologic Quadrangle Map GQ-215.

Lipman, P.W., Christiansen, R.L., and O'Connor, J.T., 1966, A compositionally zoned ash-flow sheet in southern Nevada: U.S. Geological Survey Professional Paper 524-F, $47 \mathrm{p}$.

Manheim, F.T., 1974, Comparative studies on extraction of sediment interstitial waters-Discussion and comment on the current state of interstitial water studies: Clay and Clay Minerals, v. 22, p. 337-343.

Montazer, P., and Wilson, W.E., 1984, Conceptual hydrologic model of flow in the unsaturated zone, Yucca Mountain, Nevada: U.S. Geological Survey Water-Resources Investigations Report 84-4345, 55 p.

Mower, T.E., Higgins, J.D., Yang, I.C., and Peters, C.A., 1994, Pore-water extraction from unsaturated tuff by triaxial and one-dimensional compression methods, Nevada Test Site, Nevada: U.S. Geological Survey Water-Resources Investigations Report 93-4144, 78 p.
Peters, C.A., Higgins, J.D., Yang, I.C., and Burger, P.A., 1992, A preliminary study of the chemistry of pore water extracted from tuff by one-dimensional compression, in Kharaka, Y.K., and Maest, A.S., eds., Proceedings of the 7th International Symposium on WaterRock Interaction, Brookfield, Vermont, Balkema, p. 741-745.

Rieke, H.H., III, and Chilingarian, G.V., 1974, Compaction of argillaceous sediments, in Developments in Sedimentology, v. 16, Amsterdam, Netherlands, Elsevier, $424 \mathrm{p}$.

Singer, A., and Muller, G., 1983, Diagenesis in argillaceous sediments, in Larsen, G., and Chilingar, G.V., eds. Diagenesis in sediments and sedimentary rocks, 2 : Amsterdam, Netherlands, Elsevier, p. 115-212.

Yang, I.C., Davis, G.S., and Sayre, T.M., 1990, Comparison of pore-water extraction by triaxial compression and high-speed centrifugation methods, in Zaporozec, A., ed., Minimizing risk to the hydrologic environment: American Institute of Hydrology, Dubuque, Iowa, Kendall/Hunt, p. 250-259.

Yang, I.C., Turner, A.K., Sayre, T.M., and Montazer, P., 1988, Triaxial-compression extraction of pore water from unsaturated tuff, Yucca Mountain, Nevada: U.S. Geological Survey Water-Resources Investigations Report 88-4189, 68 p.

Zimmerman, R.M., and Finley, R.E., 1987, Summary of geo-mechanical measurements taken in and around G-Tunnel Underground Facility, NTS: Albuquerque, Sandia National Laboratories, SAND86-1015, 152 p. 


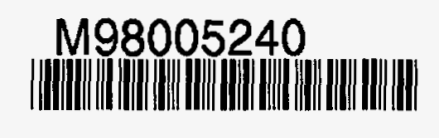

Report Number (14) US65/WRIR- $-96-4281$

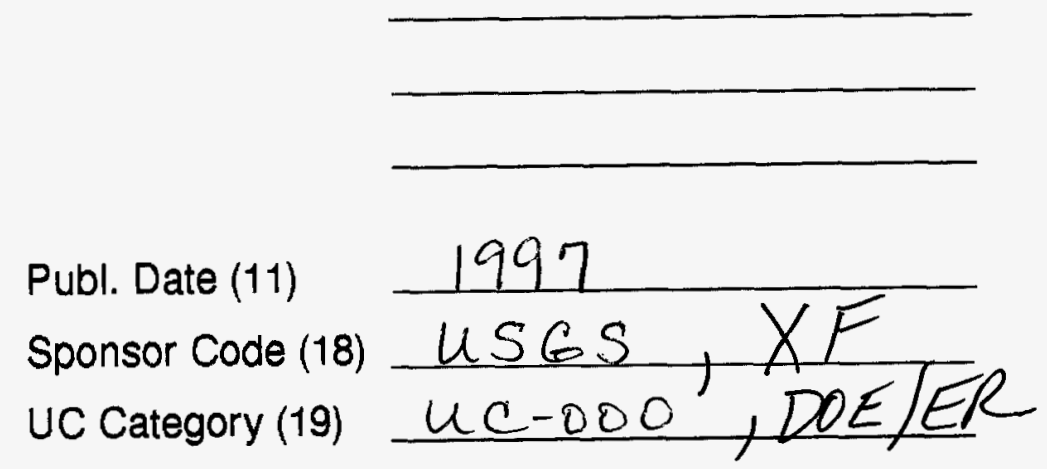

\section{4}

